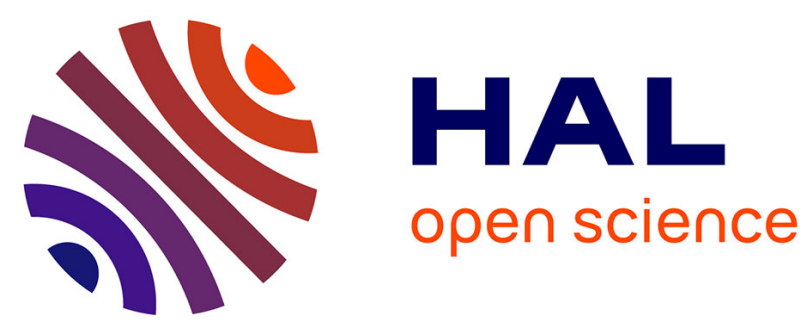

\title{
A Dufrenoyia (Ammonoidea, Deshayesitidae) fauna from Germany: Evidence for D. furcata Zone deposits at the lower-upper Aptian boundary
}

Jens Lehmann, Luc Bulot

\section{- To cite this version:}

Jens Lehmann, Luc Bulot. A Dufrenoyia (Ammonoidea, Deshayesitidae) fauna from Germany: Evidence for D. furcata Zone deposits at the lower-upper Aptian boundary. Cretaceous Research, 2020, 116, pp.1-14. 10.1016/j.cretres.2020.104546 . hal-03016302

\section{HAL Id: hal-03016302 \\ https://hal.science/hal-03016302}

Submitted on 20 Nov 2020

HAL is a multi-disciplinary open access archive for the deposit and dissemination of scientific research documents, whether they are published or not. The documents may come from teaching and research institutions in France or abroad, or from public or private research centers.
L'archive ouverte pluridisciplinaire HAL, est destinée au dépôt et à la diffusion de documents scientifiques de niveau recherche, publiés ou non, émanant des établissements d'enseignement et de recherche français ou étrangers, des laboratoires publics ou privés. 
1 A Dufrenoyia (Ammonoidea, Deshayesitidae) fauna from Germany:

2 Improving the correlation of the lower/upper Aptian boundary

3

4 Jens Lehmann ${ }^{a}$, Luc Georges Bulot ${ }^{\mathrm{b}, \mathrm{c}}$

5 With 9 figures, and 1 table

6 a Faculty of Geosciences, University of Bremen, Klagenfurter Strasse, 28357

7 Bremen, Germany. E-mail address: jens.lehmann@uni-bremen.de

8

9 b. Aix-Marseille Université, CNRS, IRD, INRA, Collège de France, Cerege, Site

10 Saint-Charles, Case 67, 3, Place Victor Hugo, 13331 Marseille Cedex 3, France;

11 bulot@cerege.fr

12 c University of Manchester, Department of Earth and Environmental Sciences,

13 North Africa Research Group, M13 9PL Manchester, UK;

14 luc.bulot@manchester.ac.uk

15

\section{ABSTRACT}

17 Dufrenoyia is a relevant ammonite genus for discussing the lower/upper Aptian 18 boundary on a supraregional scale. We present the first comprehensive account 19 on the genus from Germany, recording the two index species Dufrenoyia furcata 20 and Dufrenoyia transitoria from the Ahaus area. This is based on a yet 21 undescribed historical collection by the German nineteenth century palaeontologist

22 Clemens Schlüter. Our stratigraphic conclusions improves the correlation of the 23 poorly-known highest lower Aptian in Germany, particularly with the well-known 24 successions in England and France. An alleged dimorphism in Dufrenoyia furcata 25 is discussed. 
26 Keywords. Ammonites; lower Aptian/upper Albian; historical material; northern

27 Germany; Correlations

\section{Introduction}

30 Almost 60 years ago Raymond Casey recommended to place the lower/upper 31 Aptian boundary at the last occurrence of Dufrenoyia, at the top of the Tropaeum bowerbanki Zone, based on the well-exposed Lower Greensand succession in southern England (Casey, 1961). In fact, in the Boreal-Atlantic subrealm Dufrenoyia furcata can be used as an alternative to the uppermost lower Aptian zonal index Tropaeum bowerbanki (Lehmann, 2015). Although this has been debated over the years (e.g. Kemper, 1971) it is now widely accepted (Reboulet et al., 2011; 2018; 2014). Our current knowledge indicates that the ammonite genus

38 Dufrenoyia is a well-established marker for recognizing the lower/upper Aptian 39 boundary in the Boreal as well as in the Tethys (Raisossadat et al., 2008), 40 whereas the distribution of other important markers like Tropaeum and 41 Australiceras is comparatively restricted (Lehmann et al., 2015).

42 The Aptian ammonites of the genus Dufrenoyia from North Germany described 43 here are a part of a collection assembled in the nineteenth century. At that time, 44 many small clay pits where existing in that area from which a large number of 45 fossils were collected. Nowadays, there is hardly any outcrops left. This is the 46 main reason why only 15 papers illustrating ammonites from in situ occurrences 47 from the Aptian in North Germany were published in the past 50 years (Kemper, 48 1971a, 1973a; Kemper and Zimmerle, 1978; Gaida et al., 1978; Kemper, 1976, , 49 1982a, , 1995; Weber, 1996; Mutterlose, 1996; Owen in Mutterlose et al., 2003; 50 Hoffmann and Mutterlose, 2011; Vespermann, 2006; Mutterlose and Wiedenroth, 
51 2009; Lehmann et al., 2012; Lehmann et al. , 2016). Among those, ammonite

52 systematic is only addressed in a couple of contributions (Owen in Mutterlose et

53 al., 2003; Hoffmann and Mutterlose, 2011) and thus each further account is 54 reasonable.

55

56

\section{Geological setting}

57 All specimens referred to here have been obtained from the vicinity of the city of Ahaus in northern Germany. During the Early Cretaceous this area was at the western rim of the Lower Saxony Basin (LSB in the following; Fig. 1). The LSB contains a several thousand meters thick sedimentary succession, spanning a

61 time interval from the latest Jurassic to the Late Cretaceous. During Aptian times, the LSB was subdivided by small swells and islands into subbasins, but generally

63 it constituted a large epicontinental sea extending to the Proto-North Sea area, 64 and connected to the (proto-)Atlantic Ocean in the southwest and northwest 65 (Kemper, 1979; Ziegler, 1990). In the distal areas predominately shales were 66 deposited, including the local expression of OAE 1a (e.g. Lehmann et al., 2012), 67 whereas towards the basin margin, silty to sandy dark-grey claystone prevailed 68 (Mutterlose and Böckel, 1998). The material described here comes from a 69 restricted southernmost extension of the LSB called the Alstätte Bay (e.g.

70 Lehmann et al., 2012; von Bargen and Lehmann, 2014; Schlak et al., 2016;

71 =Alstätte Embayment of Kemper, 1973b and Herngreen et al., 1994). It represents

72 one of several small bays at the southwestern margin of the LSB (Wolburg, 1954;

73 Schott et al., 1969). Sediments of the Alstätte Bay were poorly exposed for many

74 decades and thus very little research was done for many years. This changed

75 fairly recently and a whole series of papers on the temporary EGW section in 
Ahaus-Alstätte that was exposed from 2009 to 2019 was published (Hoffmann and Mutterlose, 2011; Lehmann et al., 2012; Bottini and Mutterlose, 2012; Mutterlose and Bottini, 2012; von Bargen and Lehmann, 2014; von Bargen et al., 2016;

Mutterlose et al., 2014; Schlak et al., 2016; Lübke and Mutterlose, 2016; Lehmann et al., 2016). However, the Ahaus area became a classic area for Aptian palaeontology in Germany already in the $19^{\text {th }}$ century due to a large number of fossiliferous, but now abandon clay pits (e.g. Ewald, 1861; Hilbck, 1867; Ziegler, 1873). It is quite surprising that the material focussed on herein can add quite a few new data to this classical and seemingly well-explored area of palaeontological research in Central Europe.

\section{Figure 1 somewhere near here}

\section{Material and conventions}

\subsection{Previously known material}

Dufrenoyia is a very rarely reported ammonite from Early Cretaceous deposits of Germany. Already von Strombeck (1858: 444) reported an ammonite, erroneously referred to as Ammonites Deshayesi, that is a Dufrenoyia since the cross section shows a distinct ventrolateral edge ("Die Kante zwischen Rücken und Seite pflegt dagegen bis ins höchste Alter hervorzustechen“).

First finds attributed to a species that is now included in Dufrenoyia were mentioned by Ewald (1861: 338; not 1860 as cited by von Koenen 1902) from the Ahaus area (Barler Berg) as Ammonites furcatus. The same specimens were later briefly described by von Koenen (1902: 202-204), referring to them as Hoplites furcatus Sowerby. Besides 10 specimens from the Ahaus area von Koenen (1902) mentions two doubtfully conspecific specimens from Weenzen, Duingen area, in 
101 the Hildesheim district. More recently, Kemper (1964: 42) referred to one of these 102 specimens in the University of Münster collection as Dufrenoya dufrenoyi 103 (d'Orbigny, 1840) [sic] - apparently the only specimen that survived until then. 104 Kemper (1971: pl. 26, fig. 2) figured Dufrenoyia furcata and since his figure 105 captions refers to being a part of the University of Münster collection it can be 106 assumed that he refers to the same specimen and actually revised his earlier 107 identification. In fact, this historical specimen remained the only material depicted 108 in the literature from Germany and consequently Kemper (1976: pl. 24, fig. 1 and, 109 1995: pl. 5, fig. 2) refigured this important find.

\subsection{New material and conventions}

112 One of us (JL) was visiting the historical collection of Clemens August Schlüter 113 (Fig. 2A) as a part of the University of Bonn collection in 2016, recognizing that the 114 Aptian/Albian part of this collection was scientifically not explored yet. All of the 115 material is housed in the Goldfuß-Museum für Paläontologie, University of Bonn, 116 Germany. Its acronym is IGPB (for "Institut für Geowissenschaften, Paläontologie, 117 Bonn"). Since these specimens are of historical importance additional to their 118 scientific value, no preparation works have been done to reveal the suture lines. 119 However, IGPB KrU16-5 is a slightly worn internal mould that shows the suture. 120 We used the suture terminology of Wedekind (1916), as applied by Kullmann and 121 Wiedmann (1970) and modified by Korn et al. (2003): E - external lobe, A 122 adventive lobe (that is $\mathrm{L}$ of traditional nomenclature), $\mathrm{U}$ - umbilical lobe (I - internal 123 lobe is not applicable for the present material). The $E / A$ (that is $E / L$ of traditional 124 nomenclature) is the saddle between $E$ and $A$ and $A / U$ (L/U of traditional 125 nomenclature) and corresponds to the saddle between $A$ and $U$. The 
126 differentiation into $U_{2}$ and $U_{3}$ is used here according to the conclusions on suture 127 ontogeny of Dufrenoyia by Schindewolf (1967). For most specimens it was not 128 possible to give conch dimensions, $\mathrm{D}$ represents the diameter, $\mathrm{U}$ the width of the 129 umbilicus (further details and measurements see Supplementary data).

130 The nineteenth century palaeontologist Schlüter (Fig. 2A) became famous by 131 publishing 164 papers on Late Cretaceous and Devonian fossils from North 132 Germany in between 1859 and 1902 (Steinmann, 1908; Riegraf and Scheer, 133 1991b, b). Many of Schlüter's papers are based on fossils collected by himself, he 134 was a successful collector from an early age (Steinmann, 1908). During the first 135 part of his career he almost exclusively published on Late Cretaceous fossils from 136 Germany and in 1878 this changed and he also concentrated on the description of 137 Devonian fossils (Riegraf and Scheer, 1991a). In fact, Early Cretaceous fossils 138 never drawn his attention, except for a paper on glacial erratics (Schlüter, 1874). 139 This is one reason why he never worked on the fossils at hand, but also because

140 he borrowed it to J. Ewald who used it together with a collection of von der Marck 141 from the same locality to give an overview, however, without figuring them (Ewald, 142 1861). Nevertheless, the Ewald (1861) paper presents identifications that are 143 referred to in the recent literature as doubtful (Klein and Bogdanova, 2013: 125) 144 and thus it is relevant to figure all of the original material that survived here.

Figure 2 somewhere near here

148 In this respect it is astonishing that Edwin Kemper never used the collection of the 149 University of Bonn. Kemper was a geologist and palaeontologist widely known for 150 his comprehensive work on the Early Cretaceous of the LSB in Germany (e.g. 
151 Kemper, 1982b; Kemper, 1987). His work comprised Aptian ammonites quite 152 intensively, but although he used historical material from various sources, he 153 probably overlooked Schlüter's collection, because the latter was widely154 recognized for his collection of Late Cretaceous and Devonian fossils only. This 155 assumption is underlined by a statement in his famous "Bentheimführer" (Kemper, 156 1976) that there is nice material is kept in the collection of Münster University and 157 the Natural History Museum in Enschede (The Netherlands).

\subsection{Locality details}

160 In 1853 quarrying first exposed Aptian sediments in the Ahaus area (Ewald, 1861). 161 This exposure is now long covered again, but together with succeeding clay pit 162 activities it is known today as the classical Barler Berg near Ahaus locality for 163 fossils in Germany (Kemper 1976; Lehmann et al., 2012). Most of the specimens 164 described here are, however, lettered in red "Wüllen" (Fig. 2C). Besides, some of 165 these have an additional label associated in the specimen box that states "Wüllen 166 bei Ahaus, Unterer Gault, C. Schlüter leg." Some labels show that Schlüter 167 identified the Dufrenoyia specimens correctly based on the state of the art of his 168 time. Several identifications are given on the labels associated, and in one case 169 (old inventory number 223, IGPB KrU16-5) a label is fixed on the specimen with 170 that information and the identification "Ammonites furcatus Sow. $=$ A. Dufrenoyi 171 d'Orb." (Fig. 2B). Apparently, Schlüter was aware of his finds, but simply did not do 172 the scientific work by himself (compare 3.2). Some fossils in the collection are 173 labelled with the locality name "Barler Berg", as also indicated by red letters on the

174 specimens (e.g. IGPB KrU15-13, a phylloceratid; IGPB KrU15-10, a pleurotomariid 175 gastropod). In this case the year of collecting is given (1899, respectively 1864). A 
176 couple of labels associated with the Dufrenoyia material states that they were 177 collected from "Wüllen" in 1863 (IGPB KrU18-10) respectively 1865 (IGPB KrU-14178 25). However, Wüllen is the name of the next larger settlement and is used 179 synonymous with "Barler Berg", that is a more precise name for indicating where 180 the former pits were located (Fig. 3). We assume both locality names are used 181 synonymous by Schlüter who, however, apparently did not changed the name 182 used for this collecting locality at one point in time. We call the locality Barler Berg 183 here, since "Wüllen" is widely used in the literature to refer to a former limestone 184 quarry (Riegraf, 1997) of Late Cretaceous (Turonian) age (e.g. Wittler, 2003; 185 Wiese, 2009; Karl et al., 2012) and even a formation in the Turonian of Westphalia 186 is named after Wüllen (Niebuhr et al., 2007).

\section{Figure 3 somewhere near here}

190 The Barler Berg locality is also called "an der Frankenmühle" (von Strombeck, 191 1858; Ewald, 1861), referring to the name of a farmyard about $1 \mathrm{~km} \mathrm{WSW}$ of the 192 Frankenmühle, as clarified by Kemper (1976: figure caption to pl. 24, fig. 1; Fig. 3). 193 This locality name was alternatively spelled "Frankemölle" (Bentz 1930) or 194 "Frankenmölle", see Kemper 1976) in historical times.

195 Hosius (1860: 68) reports an alternation of glauconitic marlstones and iron196 containing sandstones, sometimes silicified, of varying hardness from the 197 Frankenmühle locality. The matrix of the specimens at hand are in general 198 accordance with this observation. All specimens show a carbonaceous matrix and 199 mostly this contains many coarse quartz grains (Fig. 2B), almost all are reddish 200 and this indicates that they are rich in iron, but there is are also a few specimens 
201 preserved in a light grey claystone. In fact, there are is an examples where a 202 specimen preserved in grey claystone is associated with a specimen in 203 carbonaceous matrix in the same box and the same label in the collection (IGPB 204 KrU14-25 and IGPB KrU14-25b). Although these two preservations indicate an 205 origin from beds of contrary rock types, this is in accordance with the alternation of 206 different lithology at one and the same spot as described by Hosius (1860).

207

208

\section{Systematic palaeontology}

209 Suborder Ammonitina Hyatt, 1889

210 Superfamily Deshayesitoidea Stoyanow, 1949

211 Family Deshayesitidae Stoyanow, 1949

212 Dufrenoyia Kilian and Reboul, 1915

213

214 Preliminary remarks. Among Cretaceous ammonoids, the Deshayesitidae show a 215 particularly large variability. As already outlined by Bersac and Bert (2015) and

216 Lehmann et al. (2016), many of the species and even genera described are in 217 need of a critical evaluation.

218 Several attempts have been made in the last two decades to evaluate the

219 intraspecific variability of the western European populations of Dufrenoyia. Large

220 number of specimens show that there is a considerable variability in the course of

221 time, but also in the individual assemblages (fossil "populations") that are from a 222 short stratigraphic interval. Such "populations" were investigated from France by

223 Martin (2003) and Dutour (2005). Interestingly these two authors outlined the

224 variability of the French "populations", but reached different systematic

225 conclusions regarding the number of taxa represented. According to Martin (2003) 
226 all specimens from SE France, including Dufrenoyia dufrenoyi (d'Orbigny, 1841),

227 fall within the range of variation of Dufrenoyia furcata (J. de C. Sowerby, 1836). To

228 the difference, Dutour (2005) retains three successive palaeospecies (? forming a

229 chronospecies): Dufrenoyia furcata, Dufrenoyia praedufrenoyi Casey, 1964 and

230 Dufrenoyia dufrenoyi. Since, a quantitative study of more than 1200 specimens

231 from Spain was conducted by García and Moreno-Bedmar (2010), who concluded

232 that sexual dimorphism occurs in $D$. furcata. These later authors did not directly

233 address the distinction between $D$. furcata and $D$. dufrenoyi, even so they kept the

234 two species separate.

235 The Mediterranean faunas on which those population studies were carried out are

236 based on juvenile pyritized internal moulds (diameter $<30 \mathrm{~mm}$ ) that cannot be

237 compared with our material. With two exceptions, our material represents later

238 growth stages with a diameter ranging from 50 to $75 \mathrm{~mm}$. Preserved suture lines

239 indicate a reconstructed diameter of at least $100 \mathrm{~mm}$ for some specimens.

240 The collection herein studied compares best with the Dufrenoyia from the Lower

241 Greensand of England monographed by Casey $(1964,1980)$. The variability of

242 these forms was recently addressed since by Bersac and Bert, 2012), who

243 concluded that the many taxa described by Casey fall within the range of variation

244 of two palaeospecies: Dufrenoyia furcata (J. de C. Sowerby, 1836) and Dufrenoyia

245 dufrenoyi (d’Orbigny, 1841).

246 Bersac and Bert (2012: 219 and 223) were aware of the limited quality of their

247 database that was compiled from literature data and photographic material. They

248 already pointed out that "the specimens studied from the Monograph were initially

249 selected by Casey to illustrate an essentially typological taxonomic division, and 
250 thus they were not sampled in order to conduct a population study" and that "the

251 number of specimens per sample is low to very low".

252 Regarding Dufrenoyia, the quantitative study performed by those authors is based

253 on 31 specimens originating from three different geographic and geological

254 settings (Hythe Beds, Kent; Carstone, Norfolk and Ferruginous Sands, Isle of

255 Wight). The precise stratigraphic position in the T. bowerbanki Zone of at least a

256 third of the material studied is either vague, inferred or unknown (Casey, 1961,

257 1964). In our opinion, the conclusions reached by Bersac and Bert (2012) can only

258 be regarded as a working hypothesis.

259

260 Dufrenoyia furcata (J. de C. Sowerby, 1836)

261 Figs. 4.A-J, 5, 6

262

2631836 Ammonites furcatus J. de C. Sowerby in Fitton, p. 339, pl. 14, fig. 17

2641925 Dufrenoya furcata; Burckhardt, p. 17; pl. 10, figs. 12, 13 (refigured

265 holotype of J. de C. Sowerby 1836)

2661930 Dufrenoyia furcata; Spath, p. 435

2671964 Dufrenoyia furcata (J. de C. Sowerby); Casey, p. 378, pl. LXII, fig. 2a-c (= 268 holotype of J. de C. Sowerby, 1836), fig. 3a-b, pl. LXIII, fig. 1, pl. LXV, fig. 1a-b, text-fig. 134d (= reproduction of J. de C. Sowerby, 1836, pl. fig. 4, 5a-b, text-fig. $140 \mathrm{~h}$.

273 1964 Dufrenoyia mackesoni Casey, pl. LXII, fig. 4a-b ; pl. LXIII, fig. 5a-b ; pl. LXV, fig. 4a-b ; text-fig. 140d. 

294 preservation.

Description. Specimens IGPB KrU17-5a and IGPB KrU17-5b are juveniles that compare with the early whorls of IGPB KrU.17-8b. At a diameter of 25 to $30 \mathrm{~mm}$, 299 the coiling is moderately involute (U/D around 0.29 , see Supplementary data) with 
300 a C whorl section. Both specimens are densely ribbed with usually one secondary

301 rib in between two primary ribs (10 primary and 11 secondary ribs per half whorl in

302 IGPB KrU17-5a: Fig. 4.E). Height of the onset of secondary ribs varies strongly,

303 either on the lower third of the flank high or at about mid-flank. All ribs weaken on

304 the ventral area. They bear small clavate tubercles on the ventral shoulder. A

305 smooth siphonal band can be observed. This feature is less expressed on IGPB

306 KrU17-5a (Fig. 4.E) than in IGPB KrU17-5b (Fig. 4.F).

307 IGPB KrU17-5c (Fig. 4.D) is a poorly preserved fragment of a juvenile marked by 308 coarser ornamentation and well expressed ventrolateral clavi and smooth siphonal 309 band.

310 Most specimens at hand are mid-size with a maximum reconstructed diameter 311 ranging from 50 to $100 \mathrm{~mm}$. The coiling is moderately involute (U/D around 0.26 , 312 see Supplementary data) with a subrectangular whorl section. The flanks are 313 ornamented by very strong, radiate and flexuous ribs, with primary ribs very 314 prominent and high on the lower and mid flank of most specimens even.

315 This is less marked on IGPB KrU14-14 (Fig. 4.I) that is distorted, but nevertheless 316 differs from all other specimens by a shallower umbilical wall and a more evolute 317 coiling; additionally, the flexuous ribbing is generally prorsiradiate and not radiate.

318 IGPB KrU17-11 (Fig. 5) is distorted and thus the ribbing is less distinct on the right 319 side of the shell, but the left side better retains the original inflation of the shell and 320 here the strength of ribbing is as prominent as usually at this growth stage. 321 However, ribbing in IGPB KrU17-11 is less flexuous and denser compared to other 322 specimens of the same size.

323 The last rib preserved in IGPB KrU17-13 (Fig. 6; estimated diameter of $70 \mathrm{~mm}$, 324 maximum whorl height of $30 \mathrm{~mm}$ ) is standing closer compared to previous ribs and 
325 the last three ribs are clearly thinner than previous ones; additional a broadening 326 of the body chamber is noted at the aperture. Furthermore, the umbilical wall is 327 shallower for the last quarter of the whorl compared to the other specimens and 328 the coiling appears more evolute.

329 There are in between 9-10 primary and secondary ribs per half whorl (Table 1).

330 Secondary ribs are regularly alternating with primary ribs to the exception of IGPB 331 KrU17-8d (Fig. 4.B) where a pair of secondary ribs can be observed between to 332 primary ribs. All specimens show ventrolateral clavi united by transversal ribs 333 across the siphonal area (i.e. without smooth siphonal band), giving the venter a 334 tabulate appearance in cross section with clear ventrolateral edges and a flat 335 venter in between.

Table 1 somewhere near here

Discussion. The Barler Berg material illustrates well the ontogenetic stage 2

340 (ventrolateral clavi bordering the smooth siphonal band) and 3 (ventrolateral clavi 341 united by transversal ribs) of the genus Dufrenoyia as defined by Casey (1964).

342 Specimens IGPB KrU17-5a (Fig. 4.E) and IGPB KrU17-5b (Fig. 4.F) clearly shows

343 that the beginning of ontogenetic stage 3 is at about 25 to $30 \mathrm{~mm}$. This is typical of 344 the Dufrenoyia from the lower part of the Tropaeum bowerbanki Zone ( $D$.

345 transitoria Subzone) of the Lower Greensand.

346 Among those, Dufrenoyia formosa and Dufrenoyia mackesoni corresponds best to 347 most of the specimens at hand. Even so their morphology is more slender than 348 that of the holotype of Dufrenoyia furcata (refigured here, Fig. 7) with a slightly 349 more involute coiling, a slightly narrower whorl section and a somewhat finer 
350 ribbing, we consider them as conspecific. This is in agreement with Bersac and

351 Bert (2012) treatment of those taxa.

352

353

354

355

\section{Figure 7 somewhere near here}

Among the juvenile specimens from Barler Berg IGPB KrU17-5b (maximum diameter 25mm, maximum diameter around $12 \mathrm{~mm}$; Fig. 4.F) corresponds well to alleged macroconchs of same size figured by García and Moreno-Bedmar (2010) in its comparatively to microconchs fine and less dense ribbing of primary and secondary ribs, and a siphonal zone that gets smooth by a discontinuous ribbing across the venter. In contrast IGPB KrU17-5a (Fig. 4.E, reconstructed maximum diameter $30 \mathrm{~mm}$, maximum whorl height $14 \mathrm{~mm}$ ) shows continuous ribs across the venter, and pretty distinct ventrolateral bullae, as well as a dense ribbing and thus could be regarded as a microconch. We cannot see a fairly evolute coiling in our juvenile microconch though, however, it needs to be emphasized that the conclusions by García and Moreno-Bedmar (2010) are based on a sample size that is statistically significant. The advantage of our material compared to that of Martin (2003) and García and Moreno-Bedmar (2010) is that it represents adult or at least subadult specimens that are supposed to show indications for dimorphism more clear than juveniles, particularly modifications of the mature body chamber (Klug et al., 2015). Another advantage is that some also allow - at least to some extend - an assessment of the juvenile stage morphology. The features of IGPB KrU17-13 (Fig. 6) described above (broadening of section and modified ribbing at the aperture, umbilical wall shallower, coiling more evolute) probably indicate that it reached maturity at its estimated maximum diameter of $70 \mathrm{~mm}$ (maximum whorl 
375 height $30 \mathrm{~mm}$ ). Contrary specimen IGPB KrU17-22 does not show signs of

376 maturity although it is larger. This fragment (maximum whorl height of $35 \mathrm{~mm}$ ) is

377 still septate at its initial part preserved, and the estimated diameter is larger than

$378120 \mathrm{~mm}$.

379 The irregularity of ribbing in this group of ammonites is remarkable. It is well-

380 known from systematic descriptions that primary and secondary ribbing is not 381 perfectly alternating in Dufrenoyia. Additionally, in several cases an individual 382 primary rib on one side of the shell corresponds to a secondary rib on the other in 383 our material (IGPB KrU14-14: Fig. 4.I; IGPB KrU17-12: Fig. 4.J, IGPB KrU14-25a:

384 Fig. 4.G) and occasionally pathologies occur (IGPB KrU14-13: Fig. 4.C; IGPB 385 KrU17-12: Fig. 4.J) or other irregularities in ornament occur (IGPB KrU17-8d: Fig. 386 4.B). A pretty extensive occurrence of pathologies could be related to a partially 387 demersal life style (e.g. Keupp and Ilg, 1992, 1994), but the general abundance of 388 irregularities is difficult to explain.

389 To summarize the Dufrenoyia material at hand is varying much. A sexual

390 dimorphism is not apparent in our material and the morphological disparity might

391 be also explained by a wide range of phenotypic plasticity.

392

393 Distribution. In the eponymous zone widely distributed in Europe (England, 394 Germany, France, Spain), Turkmenistan, northern Caucasus in Russia, 395 Mangyshlak peninsula in Kazakhstan (Casey, 1964; Kemper, 1976; Ropolo et al., 396 2006; García and Moreno-Bedmar, 2010). Not all of the non-European 397 occurrences are certain, as well as the records from Egypt (Aly, 2006) and Japan 398 (Obata et al., 1982). 
Dufrenoyia transitoria Casey, 1961

401 Figs. 8,9

402

4031961 Dufrenoyia transitoria sp. nov., Casey, p. 594; pl. 83, figs. 3a-b.

4041964 Dufrenoyia transitoria Casey, Casey, p. 388, pl. LXV, fig. 6, pl. LXVI, fig. 2a-b

405 (= CASEY, 1961, pl. 83, fig. 3a-b), fig. 3a-b, text-fig. 140b, 141, 142.

406

407 A specimen from Spain that is doubtfully representing the species from our point of

408 view was figured by Moreno-Bedmar et al. (2012: appendix fig. 6i)

409

410 Material. 2 specimens, IGPB KrU16-5 (former inventory number 223) and IGPB

411 KrU18-23.

412

413 Description. The best preserved specimen (IGPB KrU16-5) is a half whorl, 414 representing a part of a phragmocone and a partial body chamber with a 415 maximum whorl height of $47 \mathrm{~mm}$ and a reconstructed maximum diameter of 416 around $95 \mathrm{~mm}$ (Fig. 8).

417 The ribbing is prominent on the flanks, but not very strong, and generally irregular.

418 The strength of the primary ribs is variable. Some are well individualised while 419 others tend to fade on the lower third of the flank. Some secondary ribs are 420 intercalated and arise on the lower third of the flank or at mid-flank; others are 421 branching from the primary ribs at an umbilical bullae; and thus have almost the 422 same appearance as the primary ribs. There are 30 primary and secondary ribs 423 per half a whorl. The ribs are very strong across the venter, more prominent 424 compared to the flanks. In cross section the venter is tabulate, with a rounded 
425 ventrolateral edge and a very slightly arched venter between the edges. The flanks

426 are broadest on the lower third of the flank. The umbilical seam is well-rounded.

427 A second fragment with a whorl height of about $90 \mathrm{~mm}$ is slightly worn, with dense,

428 weak but fairly broad and slightly flexuous ribs that are most prominent near the 429 umbilicus and at the ventrolateral edge. Occasionally secondary ribs are 430 intercalated that arise on the upper flank; the ribs are crossing the venter less 431 prominently.

Although the surface of IGPB KrU16-5 is slightly worn the characteristics of the suture line is fairly well-visible on the penultimate suture of the right side of the

437 shell (Fig. 9). The E lobe is slender and high, the A lobe is the most prominent 438 element of the suture line, trifid and barely symmetrical. Lobe $U_{2}$ is trifid and 439 asymmetrical. The U3 is very small, located just above the umbilical edge, in 440 comparison with the $U_{2}$, and little frayed. The $E / A$ saddle is broader than the $A$ 441 lobe and shows a deep and moderately broad incision in the middle. The $A / U_{2}$ 442 saddle is prominent, symmetrical, with a deep and moderately broad incision in the 443 middle.

445 Discussion. An early tendency to weak ornament (called "rapid degeneration of 446 sculpture" by Casey, 1964) is characteristic for this species and the cross-section 447 matches well the cross section given by Casey (1964: Fig. 140b). The suture line 448 was described by Casey (1964: 388) as „with subquadrate ventral lobe and 449 symmetrically trifid first lateral lobe“. His ventral lobe corresponds to the external 
450 lobe and the first lateral lobe is the A lobe (see conventions in chapter 3.2). A

451 subquadrate external lobe is also reported for the earliest ontogeny by

452 Schindewolf (1967), in a juvenile suture referred to as representing Dufrenoyia

453 dufrenoyi, but the $\mathrm{E}$ is well-visible in IGPB KrU16-5 and is in fact higher and

454 slender. IGPB KrU16-5 agrees in having a trifid A, however, it is not symmetrical.

455 Lobes and saddles are less regularly frilled with stouter folioles and lobules (sensu

456 Yacobucci and Manship, 2011) compared to the suture lines figured by Casey

457 (1964: pl. 66, fig. 3a, b; text-fig. 141), and thus the general appearance of the

458 suture line is less symmetrical in IGPB KrU16-5. The surface of IGPB KrU16-5 is

459 slightly worn and it is most likely that these differences are due to a less

460 favourable preservation of this feature compared to the Lower Greensand

461 specimens.

462 Bersac and Bert (2016) regards Dufrenoyia transitoria as one of the slender

463 morphologies of $D$. furcata. In our opinion, $D$. transitoria has a highly distinctive

464 dense and irregular ribbing style that do not compare with any other Dufrenoyia

465 from the Lower Greensand. As such, we believe that the species should be kept

466 separate until more material comes available to discuss Bersac and Bert's view.

467 Distribution. Outside England and Germany, the species was identified the Paris 468 basin (Amédro and Matrion, 2004). Occurrences from Romania (Avram, 1976) and 469 southeast France (Ropolo et al., 2006) are poorly documented (ventral view not 470 illustrated) and cannot be ascertained. Moreno-Bedmar et al. (2010) illustrated a 471 single specimen from Spain that superficially match $D$. transitoria. The ribbing style 472 and ventral area are closer to those of $D$. dufrenoyi from the same locality than to 473 typical $D$. transitoria. 
475

476

477 Germany that was derived from the stratigraphical scheme for the Lower

478 Greensand in southern England established by Casey (1961 and succeeding 479 publications). Kemper $(1971,1995)$ used both, Dufrenoyia furcata and Tropaeum 480 bowerbanki, as a zonal index to characterize the highest lower Aptian (Fig. 10).

481 The occurrence of both species was later used to correlate the lower/upper Aptian 482 boundary between both areas (Casey et al., 1998), although the British scheme is 483 formally slightly different. Casey (1961) defined a Tropaeum bowerbanki Zone, 484 subdivided into a Dufrenoyia transitoria Subzone at the base and a Cheloniceras 485 (Cheloniceras) meyendorfi Subzone at the top. This interval characterises the 486 uppermost lower Aptian and the genus Dufrenoyia ranges from its base to close to 487 its upper limit (Casey et al 1998: Fig. 6).

488 Casey et al. (1998) retained this zonation, and unequivocally stated that they 489 regard the Tropaeum bowerbanki Zone as a synonym for the Dufrenoyia furcata 490 Zone (p. 530). A correlation with the West Mediterranean province is thus clear, in 491 fact a Dufrenoyia furcata Zone is widely used in this part of the Tethys (Reboulet 492 et al., 2009; 2011; 2018; 2014), but obscured by different zonal names. This is the 493 reason why we prefer to use a Dufrenoyia furcata Zone. It makes sense to 494 homogenize the biostratigraphical zonation since $D$. furcata can be recognized in a 495 much wider area than Tropaeum bowerbanki.

496 Figure 10 somewhere near here

498 499

\section{Morphochange and its palaeoenvironmental background}


500 Representatives of the ammonite family Deshayesitidae are widely known as

501 abundant in shallow habitat, less dominant in hemipelagic settings (e.g. the

502 Vocontian basin and Carpathian belt), since we know that Deshayesites itself is

503 missing in pelagic deep-water (Mikhailova and Baraboshkin, 2009). Despite the

504 fact that it is a challenging field, some studies try to link the distribution of

505 morphotypes to facies respectively environmental change (Martin, 2003; Lehmann

506 et al., 2016). In the case of Deshayesites it has been demonstrated that variability

507 among alleged chronospecies of this family is steered by palaeoenvironmental

508 change and thus might eventually lead to divergent selection (Lehmann et al., 509 2016).

510 In southern France, Martin (2003) reports a change to coarser ornamentation

511 through time in Dufrenoyia. The average number of ribs per whorl changes from

51237 to 28 in the three succeeding "populations" (for each "population" material from

513 different localities is involved) individualised by this author. This trend is

514 interpreted as an adaptive reaction to prograding shallow water facies.

515 This appears to be opposite to the changes interpreted for Deshayesites

516 (Lehmann et al., 2016), but agrees with the idea of a principal tendency of strongly

517 tuberculated ammonites, with depressed cross-sections, prefer nearshore deposits

518 (Wilmsen and Mosavinia, 2011). The Dufrenoyia material at hand shows primarily

519 a coarse ornament and the high number of quartz grains shows that they were

520 embedded in a turbulent water setting. However, a straightforward transfer of the

521 morphochange pattern observed for Dufrenoyia by Martin (2003) to the Barler

522 Berg fauna is impossible. Our coarsely ribbed specimens could be interpreted with

523 corresponding to Marin's (2003) upper population sample, but the density of

524 ribbing is different and our sample is not statistically relevant. As long as we need 
525 to deal with historical collections of Dufrenoyia from North Germany this issue 526 cannot be solved any further.

527

528 Acknowledgements

529 We are am indebted to Georg Heumann (Bonn) for giving access to the Schlüter 530 collection and his comprising support of this project. Markus Bertling (Münster) is 531 thanked for giving access to the collection at the University of Münster. Martin 532 Krogmann (Bremen) took the photos.

533 


\section{References}

Aly, M.F., 2006. Aptian cephalopods from Gabal Abu Ruqum, north Sinai, Egypt. Egyptian Journal of Paleontology 6, 89-123.

Amédro, F., Matrion, B., 2004. Les ammonites aptiennes de la bordure orientale du bassin de Paris: un aperçu. Bulletin Annuel de l'Association Géologique Auboise 24-25, 75-80.

Avram, E., 1976. Les fossiles du flysch éocrétacé et des calcaires tithonique des hautes vallées de la Doftana et du Tirlung (Carpates Orientales). Mémoires Institut de Géologie et de Géophysique 24, 5-74.

Bentz, A., 1930. Blatt Ottenstein, Nr. 2139, in: Landesamt, P.G. (Ed.), Berlin, p. 93.

Bersac, S., Bert, D., 2012. Ontogenesis, variability and evolution of the Lower Greensand Deshayesitidae (Ammonoidea, Lower Cretaceous, Southern England): reinterpretation of literature data; taxonomic and biostratigraphic implications. Annales du Muséum d'Histoire Naturelle de Nice 27, 197-270.

Bersac, S., Bert, D., 2015. Two ammonite species under the same name: Revision of Deshayesites deshayesi (d'Orbigny, 1841) based on topotype material (Lower Aptian, Lower Cretaceous, Northeast of France). Annales de Paléontologie 101(4), 265-294.

Bersac, S., Bert, D., 2019. The lower Aptian ammonites of the Les Ferres Aptian Basin(Lower Cretaceous, Southeast of France)Part I: Introduction and biostratigraphy. Carnets de Géologie/Notebooks on Geology 19(9), 149183. 
560 Bottini, C., Mutterlose, J., 2012. Integrated stratigraphy of Early Aptian black shales in the Boreal Realm: calcareous nannofossil and stable isotope evidence for global and regional processes. Newsletters on Stratigraphy 45(2), 115-137.

564 Burckhardt, C., 1925. Faunas del Aptiano de Nazas (Durango), 45. Mexico City, 565 pp. 1-71.

Casey, R., 1961. The stratigraphical palaeontology of the Lower Greensand. Palaeontology 3(4), 487-621.

568 Casey, R., 1964. A monograph of the Ammonoidea of the Lower Greensand. Part V. Palaeontographical Society Monographs 117, 289-398.

570 Casey, R., Bayliss, H.M., Simpson, M.I., 1998. Observations on the lithostratigraphy and ammonite succession of the Aptian (Lower Cretaceous) Lower Greensand of Chale Bay, Isle of Wight, UK. Cretaceous Research 19(3-4), 511-535.

574 Delanoy, G., Moreno-Bedmar, J.A., Ruiz, J.J., Tólos Lládser, D., 2013. Xerticeras gen. nov., a new genus of micromorphic heteromorph ammonite (Ancyloceratina, Ancyloceratidae) from the lower Aptian of Spain. Carnets de Géologie/Notebooks on Geology 2013(A02), 89-103.

578 Ewald, J., 1861. Über die fossile Fauna des unteren Gault bei Ahaus in 579 Westphalen. Monatsberichte der Königlichen preussische Akademie des Wissenschaften zu Berlin 1860, 332-349.

582

Fitton, W.H., 1836. Observations on strata between the Chalk and the Oxford Oolite, in the South-east of England, Transactions of the Geological Society Serie 2. London, pp. 1-103-334 (183 twice) + appendix: 335-390. 
584 Gaida, K.-H., Kemper, E., Zimmerle, W., 1978. Das Oberapt von Sarstedt und seine Tuffe. Geologisches Jahrbuch A 45, 43-123.

586

587

588

589

590

591

592

593

594

595

596

597

598

599

600

601

602

603

604

605

606

607

García, R., Moreno-Bedmar, J.A., 2010. Dufrenoyia furcata (Sowerby, 1836) ammonite aptiense del Aptiense inferior (Cretácico inferior) del Perelló (Tarragona), in: Moreno-Azanza, M., Díaz-Martínez, I., Gasca, J.M., Melero-Rubio, M., Rabal-Garcés, R., Sauqué, V. (Eds.), VIII Encuentro de Jóvenes Investigadores en Paleontología, volumen de actas, Cidaris, 30, pp. $129-137$.

Herngreen, G.E.W., Hartkopf-Fröder, C., Ruegg, G.H.J., 1994. Age and depositional environment of the Kuhfeld Beds (Lower Cretaceous) in the Alstätte Embayment (West Germany, East Netherlands) Geologie en Mijnbouw 72, 375-391.

Hilbck, A., 1867. Geognostische Darstellung des Eisenstein -Vorkommens in der älteren Kreideformation von Ahaus. Zeitschrift für das Berg- Hütten und Salinen-Wesen in dem Preussischen Staate 15, 108-127.

Hoffmann, R., Mutterlose, J., 2011. Stratigraphie und Cephalopodenfauna des Unter-Apt von Alstätte (NRW). Geologie und Paläontologie in Westfalen 80, 43-59.

Hosius, A., 1860. Beiträge zur Geognosie Westphalens. Zeitschrift der deutschen geologischen Gesellschaft 12, 48-96.

Hyatt, A., 1889. Genesis of the Arietidae, Smithonian Contributions to Knowledge 673. Washington, pp. 1-XI \& 239.

Karl, H.-V., Nyhuis, C.J., Schöllmann, L., 2012. The first shell remains of Rhinochelys pulchriceps (Owen, 1851) from the Upper Cretaceous of NW 
608

609

610

Germany (Testudines: Protostegidae). Studia Palaeocheloniologica 4, 143151.

Kemper, E., 1964. Einige Cephalopoden aus dem Apt des westlichen Norddeutschland. Fortschritte in der Geologie von Rheinland und Westfalen 7, 31-66.

Kemper, E., 1968. Geologischer Führer durch die Grafschaft Bentheim und die angrenzenden Gebiete, Heimatverein der Grafschaft Bentheim, Nordhorn \& Bentheim, pp. 1-172.

Kemper, E., 1971a. Zur Gliederung und Abgrenzung des norddeutschen Aptium mit Ammoniten. Geologisches Jahrbuch 89, 359-390.

Kemper, E., 1971b. Geologischer Führer durch die Grafschaft Bentheim und die angrenzenden Gebiete, Heimatverein der Grafschaft Bentheim, Nordhorn \& Bentheim, pp. 1-172.

Kemper, E., 1973a. Beobachtungen an Unterkreideammoniten im deutschholländischen Grenzgebiet zwischen Rheine, Bentheim und Winterswijk. Teil 2. Grondboor en Hamer 20(6), 256-258.

Kemper, E., 1973b. The Aptian and Albian stages in northwest Germany, in: Casey, R., Rawson, P.F. (Eds.), The Boreal Lower Cretaceous, Geological Journal Special Issue. Seel House Press, Liverpool, 5, pp. 345-359.

Kemper, E., 1976. Geologischer Führer durch die Grafschaft Bentheim und die angrenzenden Gebiete mit einem Abriß der emsländischen Unterkreide, Heimatverein der Grafschaft Bentheim, Nordhorn \& Bentheim, pp. 1-206.

Kemper, E., 1979. Die Unterkreide Nordwestdeutschlands. Ein Überblick, in: Wiedmann, J. (Ed.), Aspekte der Kreide Europas, IUGS (International 
Union of Geological Sciences) Series A. E. Schweizerbart'sche Verlagsbuchhandlung, Nägele \& Obermiller, Stuttgart, 6, pp. 1-9.

634 Kemper, E., 1982a. Die Ammoniten des späten Apt und frühen Alb Nordwestdeutschlands, in: Kemper, E. (Ed.), Das späte Apt und frühe Alb Nordwestdeutschlands, Versuch der umfassenden Analyse einer Schichtenfolge, Geologisches Jahrbuch. Schweizerbart, Stuttgart, A 65, pp. 553-577.

Kemper, E., 1982b. Das späte Apt und frühe Alb Nordwestdeutschlands, Versuch der umfassenden Analyse einer Schichtenfolge, Geologisches Jahrbuch. Schweizerbart, Stuttgart, pp. 5-703.

Kemper, E., 1987. Das Klima der Kreidezeit, Geologisches Jahrbuch. Bundesanstalt für Geowissenschaften und Rohstoffe, Stuttgart, p. 399.

Kemper, E., 1995. Die Entfaltung der Ammoniten und die Meeresverbindungen im borealen Unter- und Mittel-Apt, in: Kemper, E. (Ed.), Die Wende Barrême/Apt Geologisches Jahrbuch. Schweizerbart'sche Verlagsbuchhandlung, Nägele \& Obermiller, Stuttgart, 141, pp. 171-199.

Kemper, E., Zimmerle, W., 1978. Der Grenz-Tuff Apt/Alb von Vöhrum. Geologisches Jahrbuch A 45, 125-143.

Keupp, H., Ilg, A., 1992. Paläopathologie der Ammonitenfauna aus dem Keupp, H., Ilg, A., 1994. Paläopathologische Nachlese zur Ammoniten-Fauna aus dem Ober-Callovium der Normandie. Berliner Geowissenschaftliche Abhandlungen E 13, 321-327. 
656

657

658

659

660

66

662

663

664

665

666

667

668

669

670

671

672

673

674

675

676

677

678

679

680

Kilian, C.C.W., Reboul, P., 1915. Contribution à l’étude des faunes paléocrétacés du sud-est de la France. I. La faune de l'Aptien inférieur des environs de Montélimar. II. Sur quelques ammonites des environs de Montélimar (Dròme), Mémoires pour servir à l’explication de la carte géologique détaillée de la France, Paris, pp. 1-288.

Klein, J., Bogdanova, T.N., 2013. Lower Cretaceous Ammonites VI. Douvilleiceratoidea \& Deshayesitoidea, in: Riegraf, W. (Ed.), Fossilium Catalogus I: Animalia. Backhuys Publishers, Leiden, 151, pp. 1-299.

Klug, C., Zatoń, M., Parent, H., Hostettler, B., Tajika, A., 2015. Mature modifications and sexual dimorphism, in: Klug, C., Korn, D., De Baets, K., Kruta, I., Mapes, R.H. (Eds.), Ammonoid Paleobiology: From anatomy to ecology, Topics in Geobiology. Springer, Dordrecht, 43, pp. 253-320.

Korn, D., Ebbighausen, V., Bockwinkel, J., Klug, C., 2003. The A-mode sutural ontogeny in prolecanitid ammonoids. Palaeontology 46(6), 1123-1132.

Kullmann, J., Wiedmann, J., 1970. Significance of sutures in phylogeny of Ammonoidea. University of Kansas Paleontological Contributions Paper 47, 1-32.

Lehmann, J., 2015. Ammonite biostratigraphy of the Cretaceous - an overview, in: Klug, C., Korn, D., De Baets, K., Kruta, I., Mapes, R.H. (Eds.), Ammonoid Paleobiology: From macroevolution to paleogeography, Topics in Geobiology. Springer, Dordrecht, 44, pp. 403-429.

Lehmann, J., Friedrich, O., von Bargen, D., Hemker, T., 2012. Early Aptian bay deposits at the southern margin of the Lower Saxony Basin: Integrated stratigraphy, palaeoenvironment and OAE 1a. Acta Geologica Polonica $62(1), 35-62$. 
681 Lehmann, J., Ifrim, C., Bulot, L.G., Frau, C., 2015. Paleobiogeography of Early 682 Cretaceous ammonoids, in: Klug, C., Korn, D., De Baets, K., Kruta, I., Mapes, R.H. (Eds.), Ammonoid Paleobiology: From macroevolution to paleogeography, Topics in Geobiology. Springer, Dordrecht, 44, pp. 229257.

Lehmann, J., von Bargen, D., Engelke, J., Claßen, J., 2016. Morphological variability in response to palaeoenvironmental change - a case study on Cretaceous ammonites. Lethaia 49(1), 73-86.

Lübke, N., Mutterlose, J., 2016. The impact of OAE 1a on marine biota deciphered by size variations of coccoliths. Cretaceous Research 61, 169-179.

Martin, E., 2003. Intraspecific variation of Dufrenoya furcata Sowerby (Ammonoidea, Ancylocerataceae, Deshayesitidae) from the Gargasian in the Vaucluse (Southern France). Mitteilungen aus dem GeologischPaläontologischen Institut der Universität Hamburg 87, 115-124.

Mikhailova, I.A., Baraboshkin, E.J., 2009. Ammonites of the genus Deshayesites from Aptian (Lower Cretaceous) sediments in the Crimea mountains. Moscow University Geology Bulletin 64(1), 29-34.

Moreno-Bedmar, J.A., Company, M., Bover-Arnal, T., Salas, R., Delanoy, G., Maurrasse, F.J.-M.R., Grauges, A., Martínez, R., 2010. Lower Aptian ammonite biostratigraphy in the Maestrat Basin (Eastern Iberian Chain,

703 Mutterlose, J., 1996. Die Litho- und Biostratigraphie des Apt der Tongruben 704 Schnermann am Rothenberg. Geologie und Paläontologie in Westfalen 45, 41-73. 
Mutterlose, J., Böckel, B., 1998. The Barremian-Aptian interval in NW Germany: a review. Cretaceous Research 19(5), 539-568.

Mutterlose, J., Wiedenroth, K., 2009. Neue Tagesaufschlüsse der Unter-Kreide (Hauterive - Unter-Apt) im Großraum Hannover - Braunschweig: Stratigraphie und Faunenführung. Berliner paläobiologische Abhandlungen $10,257-288$.

Mutterlose, J., Bottini, C., 2012. Stratigraphie und kalkige Nannofossilien des Unter-Apt von Alstätte (NRW). Geologie und Paläontologie in Westfalen 84, $5-15$.

Mutterlose, J., Bottini, C., Schouten, S., Sinninghe Damsté, J.S., 2014. High seasurface temperatures during the early Aptian Oceanic Anoxic Event 1a in the Boreal Realm. Geology 42(5), 439-442.

Mutterlose, J., Bornemann, A., Luppold, F.W., Owen, H.G., Ruffell, A.H., Weiss, W., Wray, D., 2003. The Vöhrum section (northwest Germany) and the Aptian/Albian boundary. Cretaceous Research 24(3), 203-252.

Niebuhr, B., Hiss, M., Kaplan, U., Tröger, K.-A., Voigt, S., Voigt, T., Wiese, F., Wilmsen, M., 2007. Lithostratigraphie der norddeutschen Oberkreide. Schriftenreihe der Deutschen Gesellschaft für Geowissenschaften 55, 1136.

Obata, I., Maiya, S., Inoue, Y., Matsukawa, M., 1982. Integrated mega- and microfossil biostratigraphy of the Lower Cretaceous Choshi Group, Japan. Bulletin of the National Science Museum, Tokyo C (Geology \& Paleontology) 8(4), 145-179.

Pictet, A., Delamette, M., Matrion, B., 2016. The Perte-du-Rhône Formation, a new Cretaceous (Aptian-Cenomanian) lithostratigraphic unit in the Jura 
mountains (France and Switzerland). Swiss Journal of Geosciences 109(2), 221-240.

Raisossadat, N., Owen, H.G., García-Mondéjar, J., Rawson, P.F., 2008. The Early Aptian ammonite biozonation in Mediterranean Province, in: Lukeneder, A. (Ed.), $1^{\text {st }}$ international Meeting on Correlation of Cretaceous Micro- and Macrofossils, Vienna $16^{\text {th }}-18^{\text {th }}$ April, 2008, Berichte der Geologischen Bundesanstalt Wien, Vienna, 74, pp. 87-88.

Reboulet, S., Klein, J., Barragán, R., Company, M., González-Arreola, C., Lukeneder, A., Raisossadat, S.N., Sandoval, J., Szives, O., Tavera, J.M., Vašíček, Z., Vermeulen, J., 2009. Report on the 3rd International Meeting of the IUGS Lower Cretaceous Ammonite Working Group, the "Kilian Group" (Vienna, Austria, 15th April 2008). Cretaceous Research 30(2), 496-502.

Reboulet, S., Szives, O., Aguirre-Urreta, B., Barragán, R., Company, M., Frau, C., Kakabadze, M.V., Klein, J., Moreno-Bedmar, J.A., Lukeneder, A., Pictet, A., Ploch, I., Raisossadat, S.N., Vašíček, Z., Baraboshkin, E.J., Mitta, V.V., 2018. Report on the 6th International Meeting of the IUGS Lower Cretaceous Ammonite Working Group, the Kilian Group (Vienna, Austria, 20th August 2017). Cretaceous Research 91, 100-110.

Reboulet, S., Szives, O., Aguirre-Urreta, B., Barragán, R., Company, M., Idakieva, V., Ivanov, M., Kakabadze, M.V., Moreno-Bedmar, J.A., Sandoval, J., Baraboshkin, E.J., Çağlar, M.K., Főzy, I., González-Arreola, C., Kenjo, S., Lukeneder, A., Raisossadat, S.N., Rawson, P.F., Tavera, J.M., 2014. Report on the 5th International Meeting of the IUGS Lower Cretaceous Ammonite Working Group, the Kilian Group (Ankara, Turkey, 31st August 2013). Cretaceous Research 50, 126-137. 
756 Reboulet, S., Rawson, P.F., Moreno-Bedmar, J.A., Aguirre-Urreta, M.B., Barragán, R., Bogomolov, Y., Company, M., González-Arreola, C., Stoyanova, V.I., Lukeneder, A., Matrion, B., Mitta, V., Randrianaly, H., Vašiček, Z., Baraboshkin, E.J., Bert, D., Bersac, S., Bogdanova, T.N., Bulot, L.G., Latil, J.-L., Mikhailova, I.A., Ropolo, P., Szives, O., 2011. Report on the 4th International Meeting of the IUGS Lower Cretaceous Ammonite Working Group, the "Kilian Group" (Dijon, France, 30th August 2010). Cretaceous Research 32(6), 786-793.

764 Riegraf, W., 1997. Nicht mehr zugänglich. Fossilien 14(4), 198.

Riegraf, W., Scheer, U., 1991a. Schlüters Schriften, in: Riegraf, W., Scheer, U. (Eds.), Cephalopoden der oberen deutschen Kreide, reprint (of the Kassel Fischer edition), 1867-1876, nomenclatoric revision and additions by Wolfgang Riegraf and Udo Scheer. Goldschneck-Verlag, Korb, pp. 8-11. pp. 6-7.

774 Ropolo, P., Moullade, M., Gonnet, R., Conte, G., Tronchetti, G., 2006. The 775 Deshayesitidae Stoyanov, 1949 (Ammonoidea) of the Aptian historical stratotype region at Cassis-La Bédoule (SE France). Carnets de Géologie/Notebooks on Geology 2006(M01), 1-46.

778 Schindewolf, O.H., 1967. Studien zur Stammesgeschichte der Ammoniten. Lieferung VI. Akademie der Wissenschaften und der Literatur 
Abhandlungen der Mathematisch-Naturwissenschaftlichen Klasse 8, 722(643)-808(130).

782

783

784

785

786

787

788

789

790

791

792

793

794

795

796

797

798

799

800

801

802

803

804

Schlak, S., Von Bargen, D., Lehmann, J., 2016. Paleoecological and paleoenvironmental implications of planktonic foraminifera from a restricted basin deposit of the Early Aptian of North Germany, in: Khosla, A., Lucas, S.G. (Eds.), Cretaceous Period: Biotic Diversity and Biogeography, New Mexico Museum of Natural History and Science Bulletin. New Mexico Museum of Natural History, Albuquerque, 71, pp. 287-298.

Schlüter, C., 1874. [Über Geschiebe des unteren Jura und der unteren Kreide im baltischen Diluvium]. Sitzungsberichte der niederrheinischen Gesellschaft für Natur- und Heilkunde, 27-29.

Schott, W., Jaritz, W., Kockel, F., Sames, C.W., Von Stackelberg, U., Stets, J., Stoppel, D., 1969. Paläogeographischer Atlas der Unterkreide von Nordwestdeutschland mit einer Übersichtsdarstellung des nördlichen Mitteleuropa. Bundesanstalt für Bodenforschung, Hannover, p. 315.

Spath, L.F., 1930. On some Ammonoidea from the Lower Greensand. Annals and Magazine of Natural History 10 5, 417-464.

Steinmann, G., 1908. Clemens August Schlueter. Sitzungsberichte der Niederrheinischen Gesellschaft für Natur- und Heilkunde zu Bonn. Naturwissenschaftliche Abteilung 1907, 96-112.

Stoyanow, A., 1949. Lower Cretaceous stratigraphy in southeastern Arizona, Memoirs Geological Society of America 38. New York, pp. 1-169.

Vespermann, J., 2006. Die neue Tongrube Vöhrum, in: Krüger, F.J. (Ed.), Braunschweiger Land, Wanderungen in die Erdgeschichte. Friedrich Pfeil, Munich, 19, pp. 133-135. 
805 von Bargen, D., Lehmann, J., 2014. Benthic ecosystem response to the deposition of lower Aptian black shales in an epicontinental sea. Cretaceous Research $51,208-224$.

808 von Bargen, D., Lehmann, J., Unverfärth, J., 2016. Ostracod response to habitat change in an early Aptian shelf sea. Palaeogeography, Palaeoclimatology,

von Koenen, A., 1902. Die Ammonitiden des norddeutschen Neocom (Valanginien, Hauterivien, Barrêmien und Aptien). Abhandlungen der königlich preussischen geologischen Landesanstalt und Bergakademie, Neue Folge 24, 1-449.

von Strombeck, A., 1858. Ueber den Gault bei der Frankenmühle unweit Ahaus. Verhandlungen des naturhistorischen Vereins für die preussischen Rheinlande und Westfalen Neue Folge 14(5), 443-450.

818 Weber, M., 1996. Die Tongrube 4 der Ziegelei Schnermann in Rothenberge: Lithound Biostratigraphie eines Ober-Aptprofils in NW-Deutschland. Geologie und Paläontologie in Westfalen 45, 75-103.

821 Wedekind, R., 1916. Über Lobus, Suturallobus und Inzision. Centralblatt für Mineralogie, Geologie und Paläontologie 1916(8), 185-195.

823 Wiese, F., 2009. Additional Prionocyclus germari (Reuss, 1845) (Cretaceous Ammonoidea, Upper Turonian) from NW Germany. Berliner paläobiologische Abhandlungen 10, 361-371.

826 Wilmsen, M., Mosavinia, A., 2011. Phenotypic plasticity and taxonomy of Schloenbachia varians (J. Sowerby, 1817) (Cretaceous Ammonoidea). Paläontologische Zeitschrift 85(2), 169-184. 
829 Wittler, F., 2003. Zur systematischen Position der Isis vertebralis Hennig 830 (Oktokorallia) zugeordneten Wurzelgeflechte in der Oberkreide. Dortmunder Beiträge zur Landeskunde, naturwissenschaftliche Mitteilungen 36/37, 223-228.

833 Wolburg, J., 1954. Schwellen und Becken im Emsland-Tektogen mit einem paläogeographischen Abriß von Wealden und Unterkreide. Beihefte zum geologischen Jahrbuch 13, 115.

836 Yacobucci, M.M., Manship, L.L., 2011. Ammonoid septal formation and suture asymmetry explored with a geographic information systems approach. Palaeontologia Electronica 14(1), 1-17.

839 Ziegler, C., 1873. Petrefakten aus dem Gault von Ahaus. Verhandlungen des 840 Naturwissenschaftlichen Vereins der preussischen Rheinlande und Westfalens. Correspondenzblatt 30, 73-74.

842 Ziegler, P.A., 1990. Geological Atlas of Western and Central Europe, Shell 843 Internationale Petroleum Maatschappij B. V., Amsterdam, pp. 1-239. 


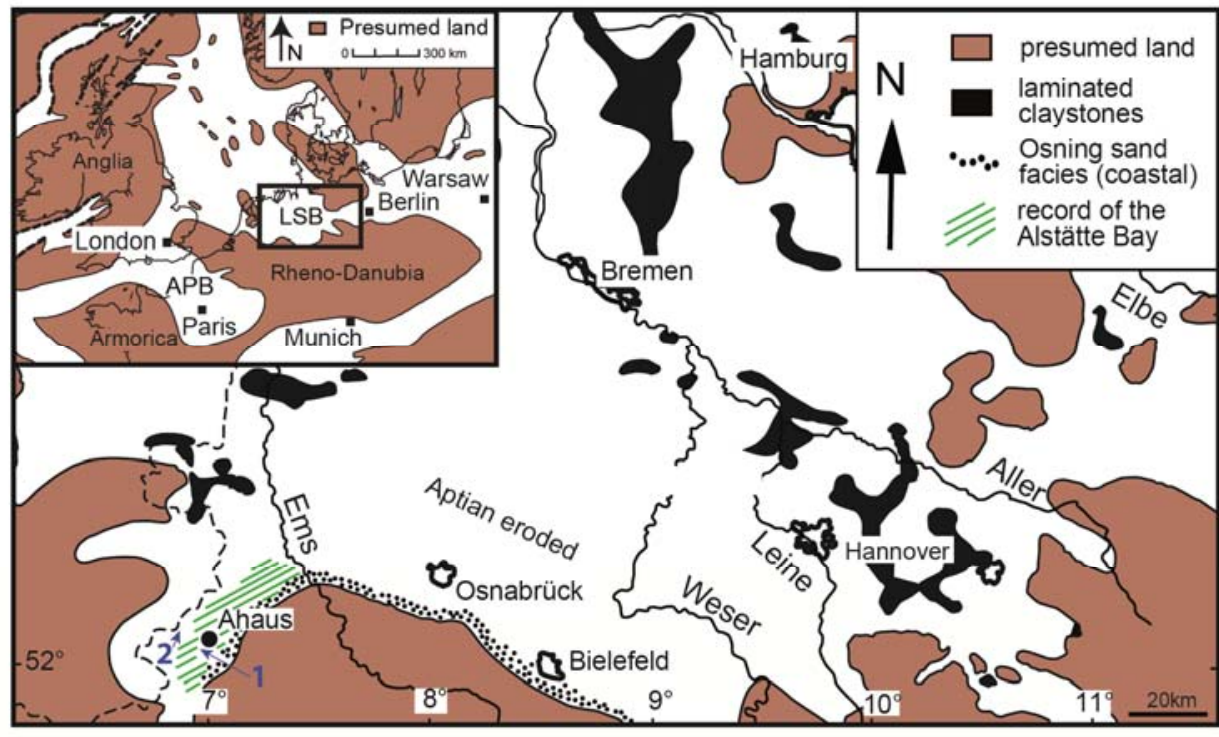

852

853 Fig. 1. Simplified palaeogeography of the Aptian in northern Europe (small map)

854 and detailed palaeogeography of the southwestern boundary of the Lower Saxony

855 Basin (LSB). APB=Anglo-Paris Basin. 1 and 2: Former Aptian sections. 1: Barler

856 Berg and Frankenmühle, 2: Alstätte EGW section. Assembled after various

857 sources, mainly Schott et al.(1969), Ziegler(1990) and Mutterlose and Böckel 858 (1998). 

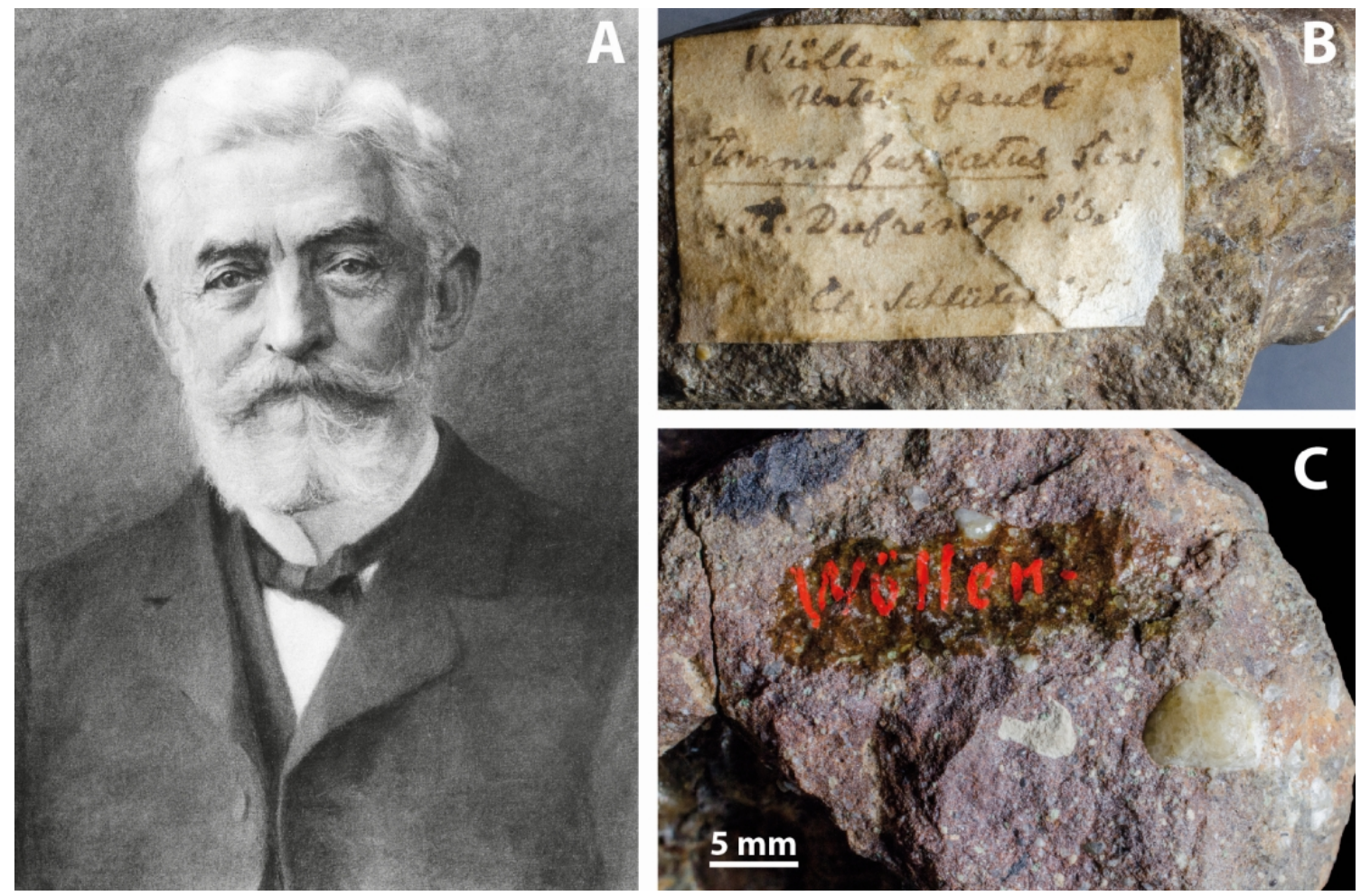

862 Fig. 2. A Portrait of Clemens Schlüter (1835-1906) who collected the fossils 863 described here (courtesy of the late J. Wiedmann). B Presumably Schlüter's 864 original handwriting on a label sticking on specimen IGPB KrU16-5: "Wüllen bei 865 Ahaus, Unterer Gault, Amm. furcatus Sow.: A. Dufrénoyi d’Orb., Cl. Schlüter leg.", 866 referring to the Barler Berg locality. C Red label (IGPB KrU17-8d) indicating the 867 locality name "Wüllen" on almost all of the specimens in the collection, showing 868 many quartz grains in a carbonaceous matrix. 


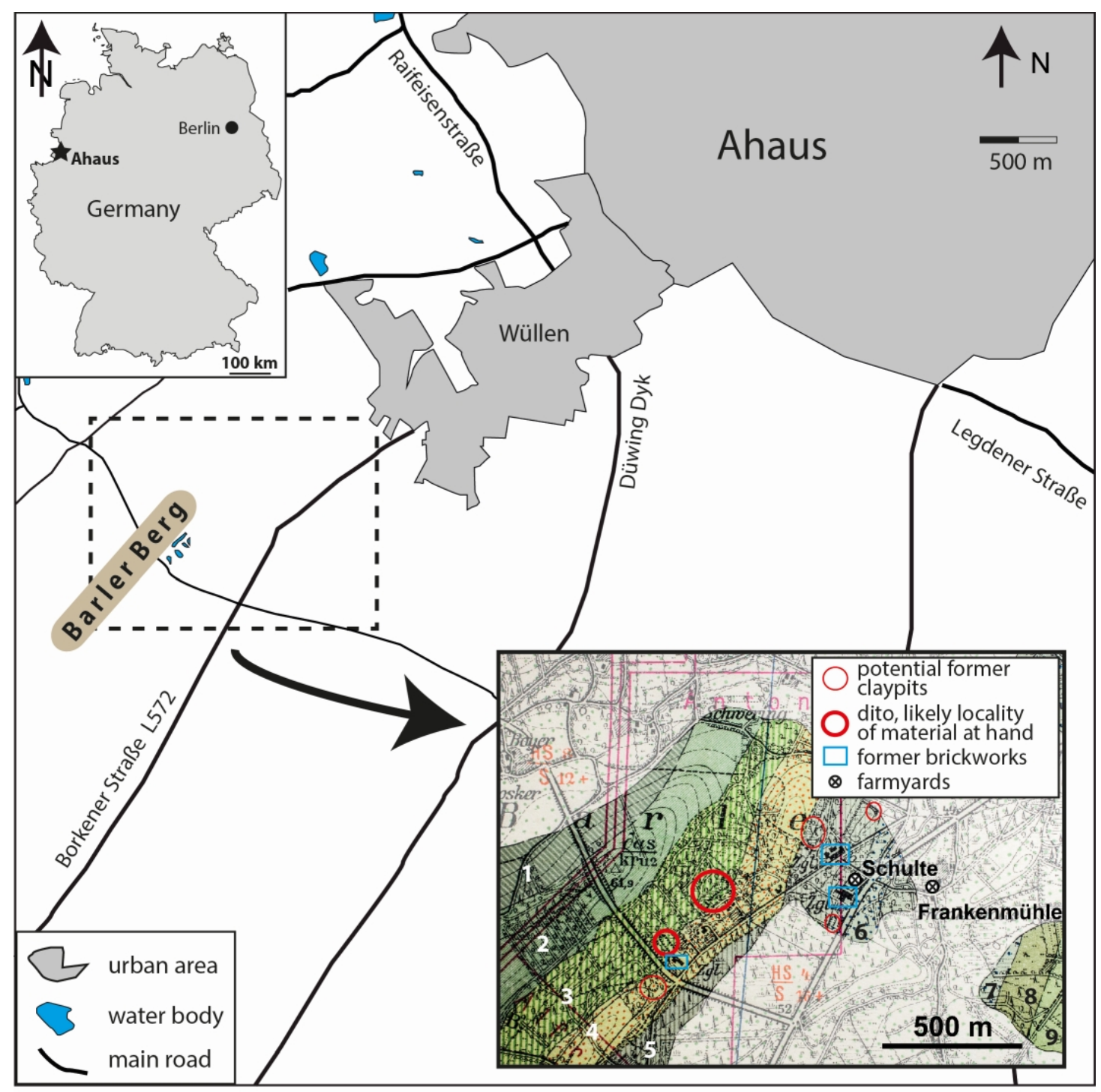

871 Fig. 3. Locality map of modern landmarks and assumed sampling localities of the

872 material described in here. Aptian fossils from this area are either labelled

873 "Wüllen", Frankenmühle" (and variations in spelling) or "Barler Berg", but this all

874 refers to the couple of potential localities marked in the geological map in the right

875 lower corner. Geological map after Bentz (1930). The latter author divided the

876 Cretaceous deposits in several mapping units that are not any longer in use, the

877 modern age assignment is given in brackets: 1 Kuhfeldschichten, = Kuhfeld Beds

878 (Valanginian), 2 Gildehauser Sandstein, = Gildehaus sandstone (Hauterivian), 3

879 "Hoplites weissi" beds (lower Aptian), 4 Rothenberg Sandstein, = Rothenberg 
880 sandstone (upper Aptian), 5 "Hoplites tardefurcatus" beds (Lower Albian), 6 881 "Minimuston", = Minimus claystone (middle Albian), 7 "Hoplites splendens" beds 882 (upper Albian, pars), 8 "Flammenmergel" (upper Albian, pars), 9 883 "Cenomanmergel", = Cenomanian marlstone (Lower Cenomanian). 884 

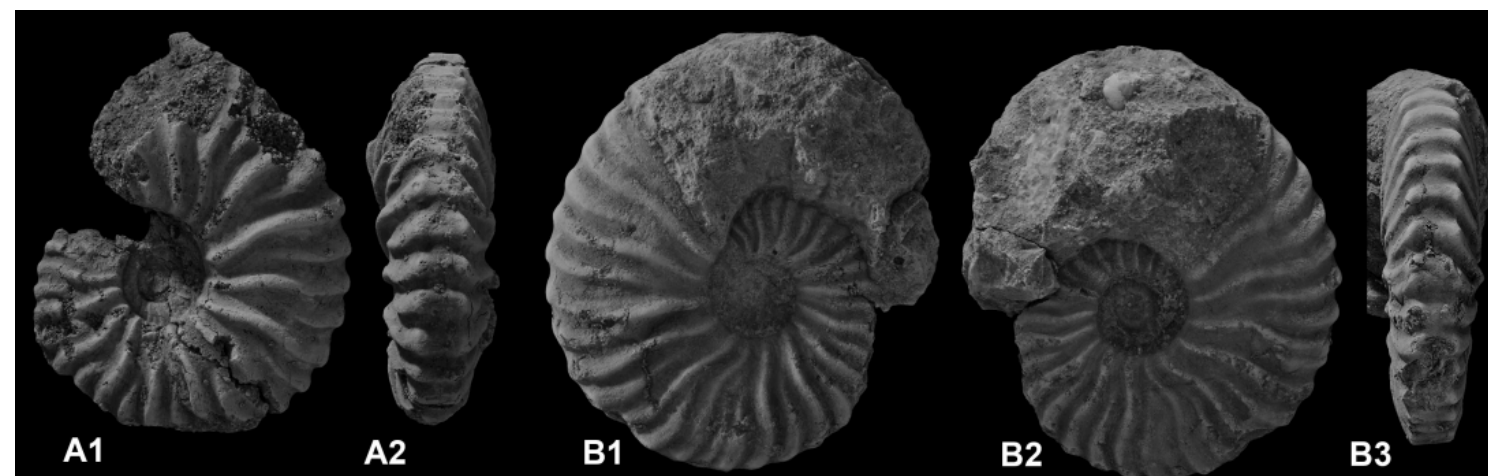

A1

A2

B1

B2

B3
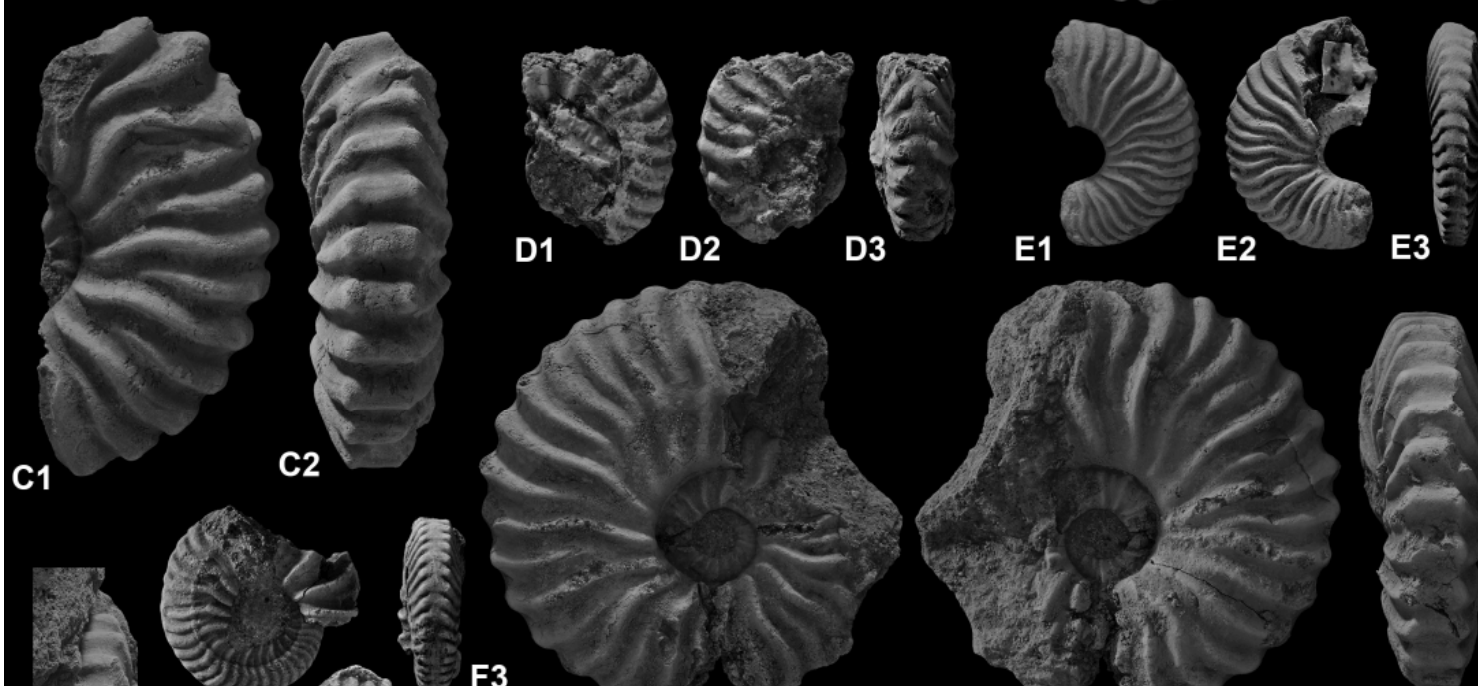

F1

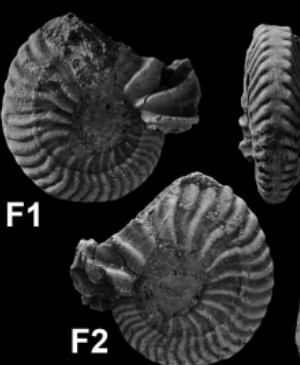

F3

G1

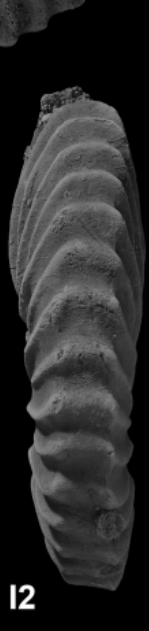

G2

G3

885
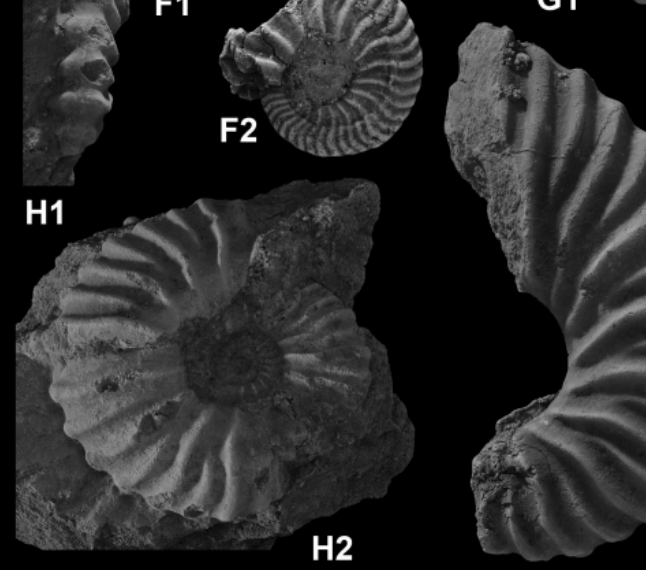

H2

11
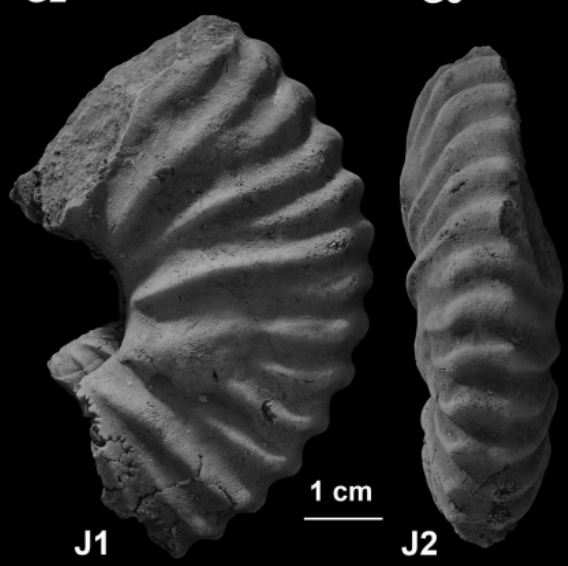

886

887 Fig. 4. Dufrenoyia furcata from the Aptian of Barler Berg near Ahaus, Germany. 888 A1-A2, IGPB KrU17-8a. B1-B3, IGPB KrU17-8d. C1-C2, IGPB KrU14-13, note 889 the pathology near the aperture in C1. D1-D3, IGPB KrU17-5c. E1-E3, IGPB $890 \mathrm{KrU17-5a}$ F1-F3, IGPB KrU17-5b. G1-G3, IGPB KrU14-25a. H1-H2, GPB 891 KrU18-11. I1-2, IGPB KrU14-14. J1-J2, IGPB KrU17-12. 
893

894

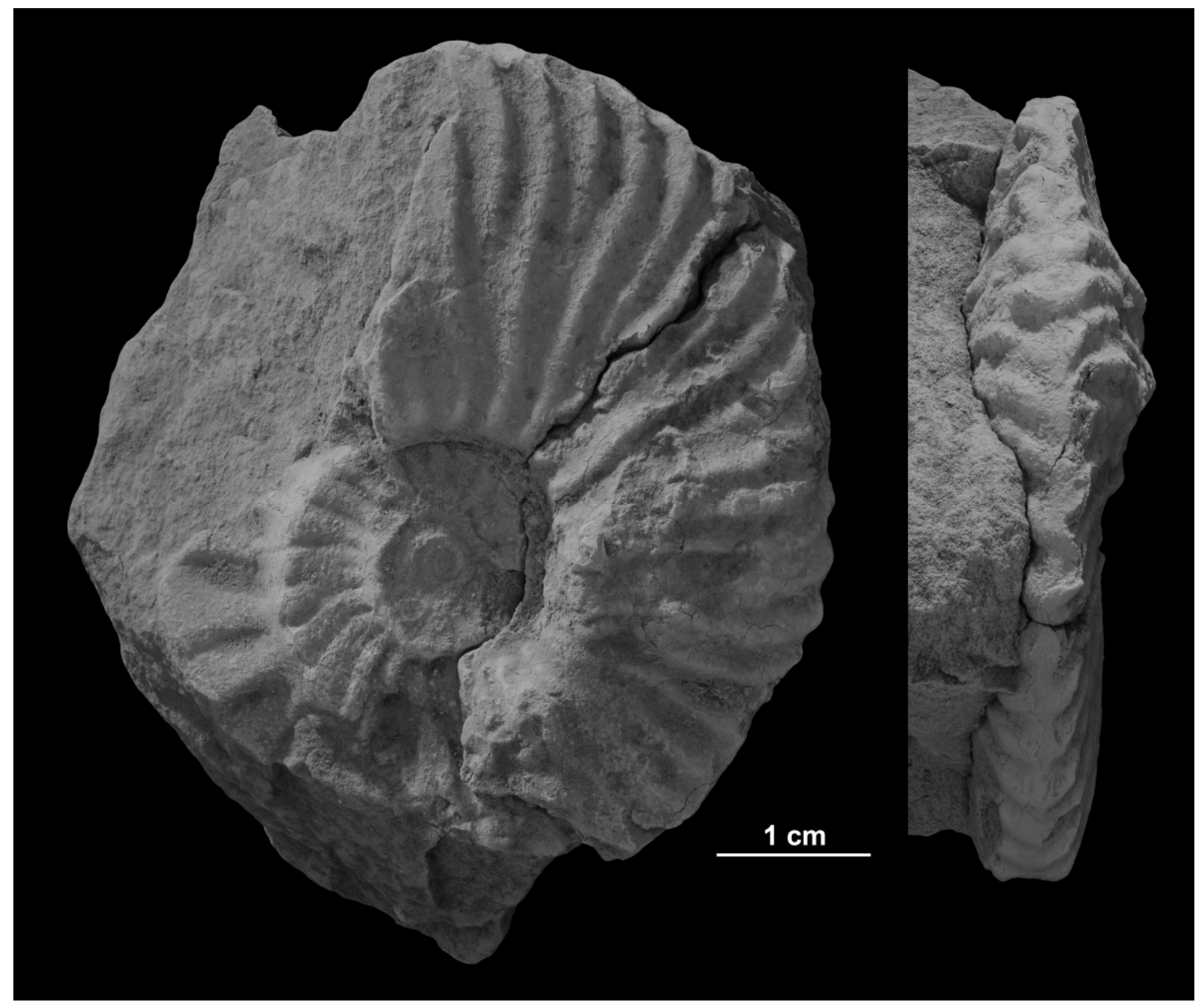

895

896 Fig. 5. Dufrenoyia furcata from the Aptian of Barler Berg near Ahaus, Germany.

897 Note the distortion of the specimen. IGPB KrU17-11.

898 


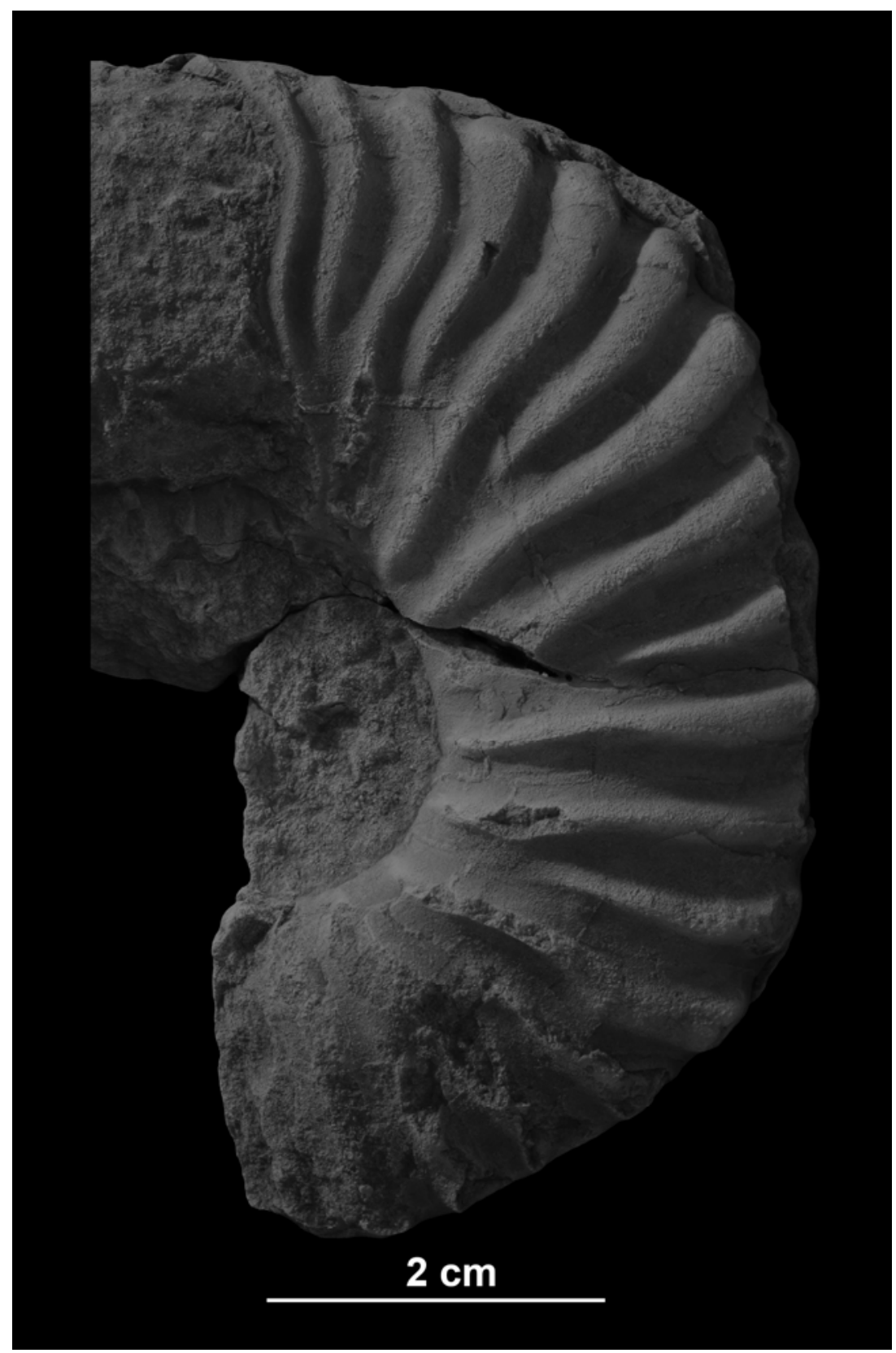

902 Fig. 6. Dufrenoyia furcata from the Aptian of Barler Berg near Ahaus, Germany. 903 Note the denser ribbing close to the aperture and the finer ultimate and 904 penultimate rib compared to all specimens depicted in Fig. 4 this specimen is 905 furthermore distinct by a shallow umbilical wall on the last quarter of the fragment. 906 IGPB KrU17-13. 


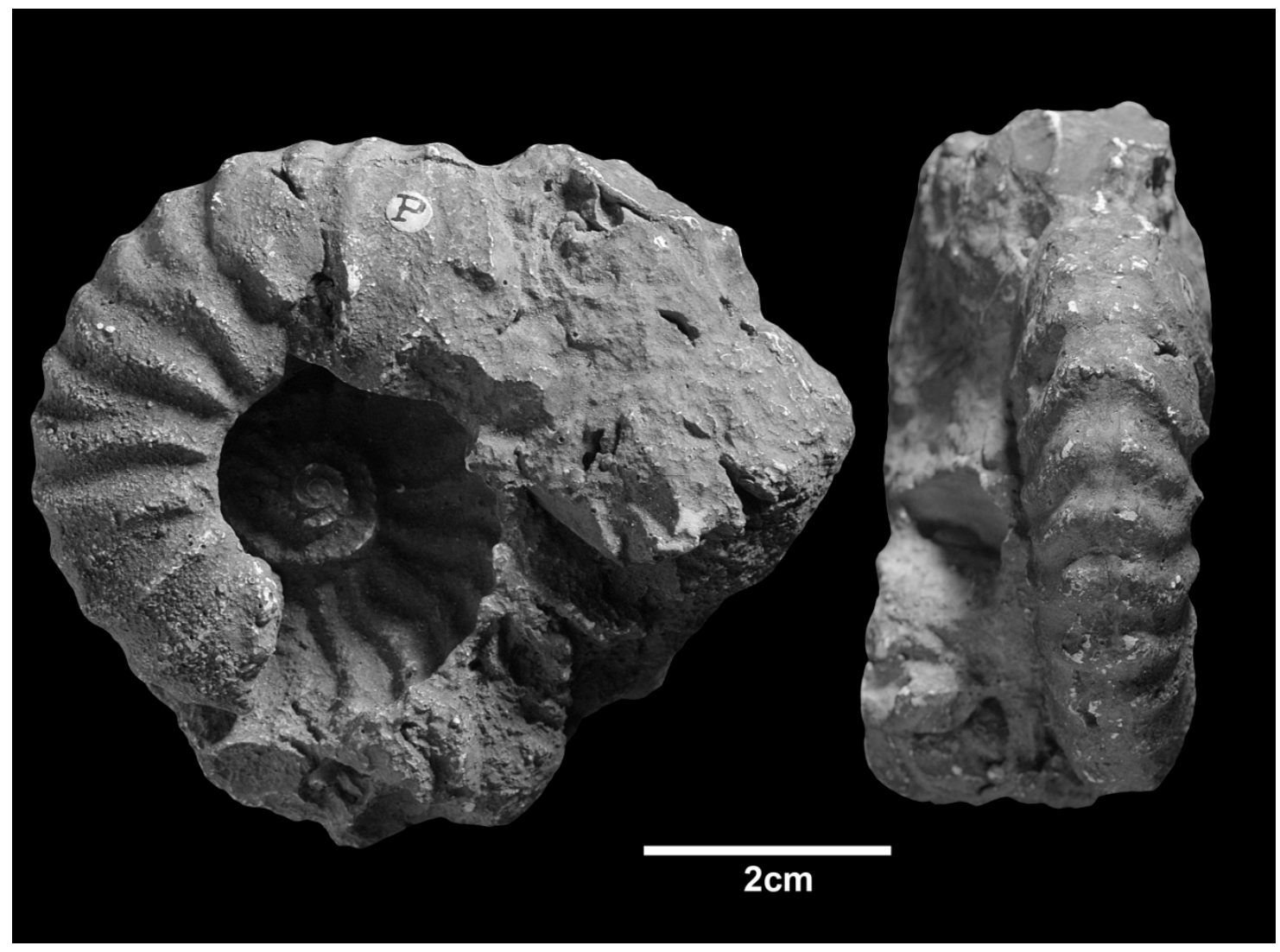

909 Fig. 7. Holotype of Dufrenoyia furcata (J. de C. Sowerby, 1836) from the Lower

910 Greensand Group of Hythe, Kent, England. Coll. Fitton, 1911. Original in the 911 British Geological Survey, Geol. Soc. Coll. 2290. Photo of plaster cast made by J.

912 O. Barlow, mould no. 1013 in the Natural History Museum London (photo JL).

913

914 


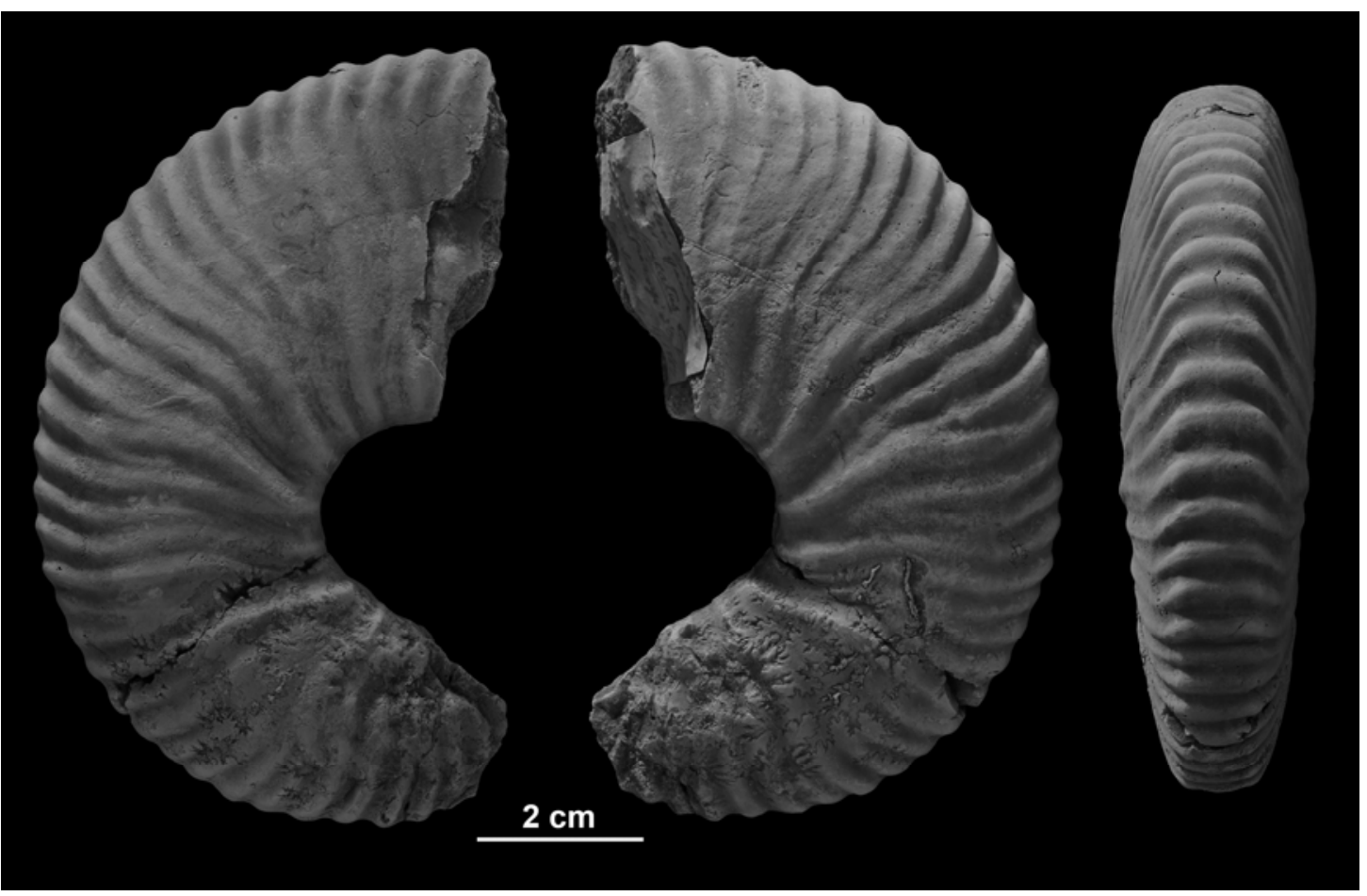

915

916 Fig. 8. Dufrenoyia transitoria from the Aptian of Barler Berg near Ahaus, Germany.

917 IGPB KrU16-5.

918

919

920

921

922

923

924

925

926

927
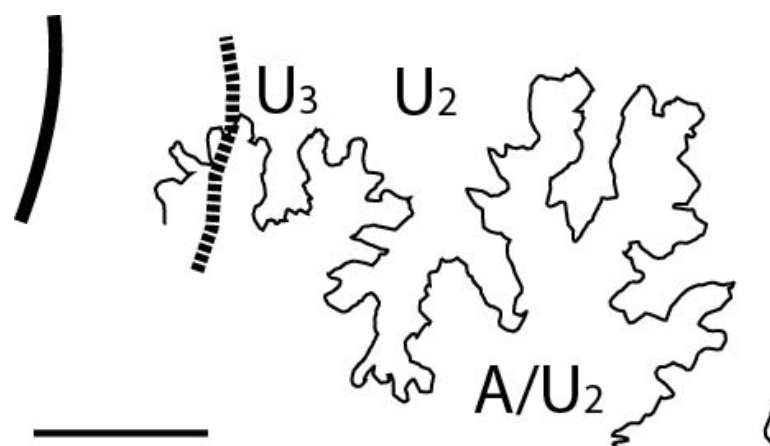

$\overline{5 \mathrm{~mm}}$

A sorsers

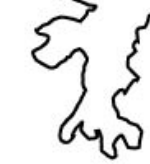




\begin{tabular}{|c|c|c|c|c|c|}
\hline \multicolumn{3}{|c|}{$\begin{array}{l}\text { stage/ } \\
\text { substage }\end{array}$} & & $\begin{array}{c}\text { Kemper 1971, } 1995 \\
\text { NW-Germany }\end{array}$ & \multirow{3}{*}{$\begin{array}{l}\text { NW-Germany } \\
\text { this paper }\end{array}$} \\
\hline \multirow{14}{*}{ 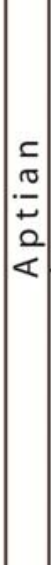 } & \multirow{5}{*}{ 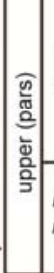 } & \multirow{3}{*}{$\begin{array}{l}\text { Parahoplites } \\
\text { nutfieldiensis }\end{array}$} & Parahoplites cunningtoni & $\begin{array}{l}\text { Parahoplites } \\
\text { nutfieldiensis }\end{array}$ & \\
\hline & & & Tropaeum subarcticum & Cheloniceras buxtorfi & \\
\hline & & & Epicheloniceras buxtorfi & $\begin{array}{l}\text { Cheloniceras laticostatum \& } \\
\text { Cheloniceras tschernyschewi }\end{array}$ & \\
\hline & & \multirow{2}{*}{$\begin{array}{l}\text { Epicheloniceras } \\
\text { martini }\end{array}$} & Epicheloniceras gracile & Tropaeum drewi & \\
\hline & & & Epicheloniceras debile & $\& T$. tenuinodosum & \\
\hline & & \multirow{2}{*}{$\begin{array}{l}\text { Tropaeum } \\
\text { bowerbanki }\end{array}$} & Cheloniceras meyendorffi & Tropaeum bowerbanki & \\
\hline & & & Dufrenoyia transitoria & \& Dufrenoyia furcata & \\
\hline & & \multirow{2}{*}{$\begin{array}{l}\begin{array}{l}\text { Deshayesites } \\
\text { deshayesi }\end{array} \\
\end{array}$} & Deshayesites grandis & \multirow{5}{*}{$\begin{array}{c}\text { Deshayesites deshayesi } \\
?\end{array}$} & \\
\hline & & & Cheloniceras parinodum & & \\
\hline & & \multirow{3}{*}{$\begin{array}{l}\text { Deshayesites } \\
\text { forbesi }\end{array}$} & Deshavesites annelidus & & \\
\hline & 离 & & $\begin{array}{l}\text { Deshayesites callidiscus } \\
\text { Deshayesites kiliani }\end{array}$ & & \\
\hline & & & Deshayesites fittoni & & \\
\hline & & \multirow{2}{*}{$\begin{array}{l}\text { Prodeshayesites } \\
\text { fissicostatus }\end{array}$} & Prodeshayesites obsoletus & Prodeshayesites tenuicostatum & \\
\hline & & & Prodeshayesites bodei & \begin{tabular}{|l|} 
Prodeshayesites bodei \\
\end{tabular} & \\
\hline
\end{tabular}

932 Fig. 10. Position of the Dufrenoyia furcata Zone in NW-Germany within a

933 biostratigraphical scheme for the Boreal Aptian and correlation with southern

934 England (Casey 1961, Casey et al. 1998). Note that Kemper (1995) is not formally

935 calling his scheme a zonation, but a succession of index species and that the

936 scheme shown is only applied to the southern part of the Lower Saxony Basin in

937 NW-Germany.

938

939

940

941

942

943

944

945

946

947 
948

949

\begin{tabular}{|l|l|l|}
\hline $\begin{array}{l}\text { Specimen } \\
\text { number }\end{array}$ & $\begin{array}{l}\text { Primary ribs/l Secondary ribs/half a whorl } \\
\text { a whorl }\end{array}$ & \\
\hline IGPB KrU25a+b & 9 & $\sim 10$ \\
\hline IGPB KrU17-8d & 10 & 10 \\
\hline IGPB KrU17-8a-c & 10 & $\sim 9$ \\
\hline IGPB KrU18-11 & $\sim 9$ & $\sim 9$ \\
\hline
\end{tabular}

950 Table 1. Rib density in Dufrenoyia furcata from the Barler Berg locality.

951

952

\section{Supplementary data}

Supplementary data

Table of material used, Lehmann \& Bulot, A Dufrenoyia (Ammonoidea, Deshayesitidae) fauna from Germany: Improving the correlation of the lower/upper Aptian boundary

\begin{tabular}{|c|c|c|c|c|c|c|c|c|c|c|c|c|}
\hline Inv.-nb. & Identification & \begin{tabular}{|l|} 
Former identification (given on \\
associated/attached labels)
\end{tabular} & Description & $\begin{array}{l}\text { Individual label } \\
\text { associated }\end{array}$ & $\begin{array}{l}\text { Locality given on the } \\
\text { (oldest) label/written on } \\
\text { specimen }\end{array}$ & $\begin{array}{l}\text { Year obtained } \\
\text { by Schlüter (if } \\
\text { given) }\end{array}$ & $\begin{array}{l}\text { Figure in } \\
\text { present paper }\end{array}$ & 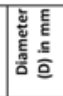 & 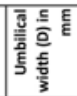 & $\frac{3}{30}$ & 产 & 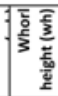 \\
\hline KrU14-13 & Dufrenoyia furcata & none & $\begin{array}{l}\text { A quarter of a body chanber fragment with } \\
\text { very last part of the phragmocone, } \\
\text { pathology close to the aperture }\end{array}$ & Yes & $\begin{array}{l}\text { Wüllen, b. Ahaus (label), } \\
\text { Wüllen (on specimen) }\end{array}$ & & Fig. 4.C1-C2 & & & & & \\
\hline KrU14-14 & Dufrenoyia furcata & none & $\begin{array}{l}\text { Body chamber fragment, about half a whorl; } \\
\text { microconch because of more evolute coiling } \\
\text { and shallow umbilical wall }\end{array}$ & Yes & $\begin{array}{l}\text { Wüllen, b. Ahaus (label), } \\
\text { Wüllen (on specimen) }\end{array}$ & & Fig. $4.11-12$ & & & & & \\
\hline KrU14-25a & Dufrenoyia furcata & Ammonites furcatus Sow. & $\begin{array}{l}\text { Fairly complete specimen and separately a } \\
\text { fragment of a couple of ribs }\end{array}$ & Yes & "Wüllen" (label) & 1865 (label) & Fig. 4.61-G3 & 255 & 14.9 & $\mid-0.27$ & 19.0 & 25.6 \\
\hline KrU14-25b & Dufrenoyia sp. & none & $\begin{array}{l}\text { Two short fragments (both belong together, } \\
\text { need to be glued together; distorted, in } \\
\text { claystone preservation (very poor) }\end{array}$ & No & & & & & & & & \\
\hline KrU16-5 & Dufrenoyia transitoria & $\begin{array}{l}\text { Ammonites furcatus Sow., A. } \\
\text { dufrenoyi d'Orb }\end{array}$ & $\begin{array}{l}\text { Body chamber fragment (slightly more than } \\
\text { a quarter whorl) and a small portion of the } \\
\text { phragmocone }\end{array}$ & Yes & $\begin{array}{l}\text { Wüllen, b. Ahaus (label), } \\
\text { Wüllen (on specimen), } \\
\text { additional paper label } \\
\text { glued on specimen }\end{array}$ & & \begin{tabular}{|l} 
Fig. 8, Fig. 9 \\
(suture), Fig. 2B \\
(label)
\end{tabular} & & & & & \\
\hline KrU17-5a & Dufrenoyia furcata & none & $\begin{array}{l}\text { Microconch when interpreted as done by } \\
\text { Garcia \& Moreno-Bedmar 2010: Fig. 1.E }\end{array}$ & No & & & Fig. 4.E1-E3 & 28.8 & 7.0 & 0.24 & & 13.6 \\
\hline KrU17-5b & Dufrenoyia furcata & Dufrenoyia furcata & $\begin{array}{l}\text { Macroconch when interpreted as done by } \\
\text { Garcia \& Moreno-Bedmar 2010: Fig. 1.F1 \& } \\
\text { 1.f2 }\end{array}$ & $\begin{array}{l}\text { No, but number } \\
\text { "226" on the } \\
\text { specimen }\end{array}$ & Wüllen (on specimen) & & Fig. 4.F1-F3 & 24.4 & 7.0 & -0.29 & 7.7 & 10.8 \\
\hline KrU17-5c & Dufrenoyia furcata & none & $\begin{array}{l}\text { Short fragment, microconch when } \\
\text { interpreted as done by as Garcia \& Moreno- } \\
\text { Bedmar 2010: Fig. 1.81 \& } 1.82\end{array}$ & No & Wüllen (on specimen) & & Fig. 4.D1-D3 & & & & & \\
\hline KrU17-8a & Dufrenoyia furcata & none & Fairly complete specimen & Yes & Wüllen, b. Ahaus (label) & & $\begin{array}{l}\text { Fig. 4.A1-A2, } \\
\text { Fig. } 10\end{array}$ & & & & & \\
\hline KrU17-8b & Dufrenoyia furcato & none & $\begin{array}{l}\text { Short fragment, a couple of ribs only, } \\
\text { belongs to KrU17-8b and needs to be glued } \\
\text { together }\end{array}$ & Yes & $\begin{array}{l}\text { Wöllen, b. Ahaus (label), } \\
\text { Wüllen (on specimen) }\end{array}$ & & & & & & & \\
\hline KrU17-8c & Dufrenoyia furcota & none & $\begin{array}{l}\text { Short fragment, a couple of ribs only, } \\
\text { belongs to Kru17-8b and needs to be glued } \\
\text { together }\end{array}$ & Yes & Wüllen, b. Ahaus (label) & & & & & & & \\
\hline KrU17-8d & Dufrenoyia furcata & none & Fairly complete specimen & Yes & $\begin{array}{l}\text { Wüllen, b. Ahaus (label), } \\
\text { Wüllen (on specimen) }\end{array}$ & & \begin{tabular}{|l} 
Fig. 4.81-B3, \\
Fig. 2C (label)
\end{tabular} & 48.4 & 12.6 & 0.26 & 13.6 & 23.5 \\
\hline KrU17-11 & Dufrenoyia furcata & none & $\begin{array}{l}\text { Distorted body chamber and negative mould } \\
\text { of inner whorls }\end{array}$ & Yes & $\begin{array}{l}\text { Wüllen, b. Ahaus (label), } \\
\text { Wüllen (on specimen) }\end{array}$ & & Fug. 5 & & & & & \\
\hline KrU17-12 & Dufrenoyia furcata & none & $\begin{array}{l}\text { Quarter of a body chamber with transition ot } \\
\text { the phragmocone, small fragment of the } \\
\text { penultimate whorl associated }\end{array}$ & Yes & $\begin{array}{l}\text { Wüllen, b. Ahaus (label), } \\
\text { Wüllen (on specimen) }\end{array}$ & & Fig. 4.J1-J2 & & & & & \\
\hline KrU17-13 & Dufrenoyia furcato & none & $\begin{array}{l}\text { Fragment of body chamber, microconch?: } \\
\text { more evolute coiling and shallow umbilical } \\
\text { wall }\end{array}$ & Yes & $\begin{array}{l}\text { Wüllen, b. Ahaus (label), } \\
\text { Wüllen (on specimen) }\end{array}$ & & Fig. 6 & & & & & \\
\hline KrU18-10 & Dufrenoyia furcata & $\begin{array}{l}\text { Ammonites furcatus Sow. }=\mathrm{A} \text {. } \\
\text { dufrenoyi d'Orb }\end{array}$ & $\begin{array}{l}\text { Body chamber fragment and a small portion } \\
\text { of the penultimate whorl }\end{array}$ & Yes & $\begin{array}{l}\text { Wüllen, b. Ahaus (label), } \\
\text { Wüllen (on specimen) }\end{array}$ & 1863 (label) & & & & & & \\
\hline KrU18-11 & Dufrenoyia furcata & none & $\begin{array}{l}\text { Fairly complete specimen, but heavily } \\
\text { crushed }\end{array}$ & Yes & $\begin{array}{l}\text { Wüllen, b. Ahaus (label), } \\
\text { Wüllen (on specimen) }\end{array}$ & & Fig. 4. H1-H2 & & & & & \\
\hline
\end{tabular}

